\title{
Response of a hydrothermal system to escalating phreatic unrest: the case of Turrialba and Irazú in Costa Rica (2007-2012)
}

\author{
D. Rouwet ${ }^{1 *}$ (D) R. Mora-Amador ${ }^{2}$, C. Ramírez ${ }^{3}$, G. González ${ }^{4,5}$, E. Baldoni ${ }^{6,7}$, G. Pecoraino ${ }^{8}$, S. Inguaggiato ${ }^{8}$, \\ B. Capaccioni ${ }^{6 \wedge}$, F. Lucchi $^{6}$ and C. A. Tranne ${ }^{6}$
}

\begin{abstract}
This study presents the first hydrogeochemical model of the hydrothermal systems of Turrialba and Irazú volcanoes in central Costa Rica, manifested as thermal springs, summit crater lakes, and fumarolic degassing at both volcanoes. Our period of observations (2007-2012) coincides with the pre- and early syn-phreatic eruption stages of Turrialba volcano that resumed volcanic unrest since 2004, after almost 140 years of quiescence. Peculiarly, the generally stable Irazú crater lake dropped its level during this reawakening of Turrialba. The isotopic composition of all the discharged fluids reveals their Caribbean meteoric origin. Four groups of thermal springs drain the northern flanks of Turrialba and Irazú volcanoes into two main rivers. Río Sucio (i.e. "dirty river") is a major rock remover on the North flank of Irazú, mainly fed by the San Cayetano spring group. Instead, one group of thermal springs discharges towards the south of Irazú. All thermal spring waters are of $\mathrm{SO}_{4}$-type (i.e. steam-heated waters), none of the springs has, however, a common hydrothermal end-member. A water mass budget for thermal springs results in an estimated total output flux of $187 \pm 37 \mathrm{~L} / \mathrm{s}$, with $100 \pm 20 \mathrm{~L} / \mathrm{s}$ accounted for by the San Cayetano springs. Thermal energy release is estimated at $110 \pm 22 \mathrm{MW}(83.9 \pm 16.8 \mathrm{MW}$ by San Cayetano), whereas the total rock mass removal rate by chemical leaching is $\sim 3000 \mathrm{~m}^{3} /$ year ( $2400 \mathrm{~m}^{3} /$ year by San Cayetano-Río Sucio). Despite Irazú being the currently less active volcano, it is a highly efficient rock remover, which, on the long term can have effects on the stability of the volcanic edifice with potentially hazardous consequences (e.g. flank collapse, landslides, phreatic eruptions). Moreover, the vapor output flux from the Turrialba fumaroles after the onset of phreatic eruptions on 5 January 2010 showed an increase of at least $\sim 260 \mathrm{~L} / \mathrm{s}$ above pre-eruptive background fumarolic vapor fluxes. This extra vapor loss implies that the drying of the summit hydrothermal system of Turrialba could tap deeper than previously thought, and could explain the coincidental disappearance of Irazú's crater lake in April 2010.
\end{abstract}

Keywords: Irazú and Turrialba volcanoes, Phreatic eruptions, Thermal springs, Fluid geochemistry, Crater lake disappearance, Water budget analysis, Hazard assessment

\section{Introduction}

Rock dissolution upon the prolonged seepage of acidic fluids from summit volcano-hydrothermal systems and crater lakes weakens the mechanical stability of a volcanic

\footnotetext{
*Correspondence: dmitri.rouwet@ingv.it

B. Capaccioni-Deceased

1 Istituto Nazionale Di Geofisica E Vulcanologia, Sezione Di Bologna,

Bologna, Italy

Full list of author information is available at the end of the article
}

edifice (Rowe et al. 1992, 1995; Delmelle et al. 2015). This process can lead to flank failure or collapses, lahars or avalanches, even during periods of apparent volcanic quiescence (López and Williams 1993; Voight and Elsworth 1997; van Wijck de Vries et al. 2000; Kerle and van Wijck de Vries 2001; Kerle et al. 2003; Reid 2004; Rouwet et al. 2014a, b; Manville 2015; Rouwet 2021). In the extreme case, it could trigger phreatic, or even high-VEI magmatic eruptions, due to the lithostatic depressurization 
of volcano flanks (Voight et al. 1983). Moreover, when fluids are dispersed into the environment, they can affect agricultural activities and eventually cause health problems to the surrounding population, also the case on the southern flank of Irazú volcano, target volcano of the current study (Parnell and Burke 1990; Delmelle and Bernard 2000; Gammons et al. 2005; Heikens et al. 2005; Löhr et al. 2005; van Rotterdam-Los et al. 2008; Varekamp 2008; Varekamp et al. 2009; van Hinsberg et al. 2010; Rouwet et al. 2014a, b).

This study aims at (1) investigating the main geochemical features of the large hydrothermal systems of Irazú and Turrialba volcanoes in Costa Rica, and (2) estimating its response to and modifications during the pre- and early syn-phreatic eruptive stage at Turrialba in 20072012 of the ongoing eruptive cycle. Irazú and Turrialba volcanoes are, respectively, located $\sim 20 \mathrm{~km}$ and $\sim 30 \mathrm{~km}$ east-northeast of the main inhabited Central Valley of Costa Rica, upwind the major cities of San José and Cartago, and the international airport in Alajuela city. When erupting, ash fall from both volcanoes can reach the metropolitan area, and can cause health issues and infrastructural damages (e.g. the March 1963 Irazú, and October 2014-September 2016 Turrialba eruptions). On the one hand, Costa Rica's highest volcano Irazú, which generally hosts a green crater lake in its main crater, has passed a stage of quiescence since its last magmatic eruptions in 1963-1965. On the other hand, Turrialba, Irazú's "twin volcano" $10 \mathrm{~km}$ northeast, resumed volcanic unrest in 2004, after it last erupted in 1864-1866. This unrest gradually evolved through time, as evidenced by (1) the arrival of magmatic $\mathrm{SO}_{2}$ in fumaroles in 2004 (Vaselli et al. 2009), (2) an increase in ${ }^{3} \mathrm{He} /{ }^{4} \mathrm{He}$ ratios in fumaroles since 2007 (Di Piazza et al. 2015; Rizzo et al. 2017), (3) expansion of fumarolic fields in and outside the active crater, culminating into plume degassing since April 2007 (Martini et al. 2010; Campion et al. 2012; Conde et al. 2014; Moussalam et al. 2014), and eventually by (4) the build-up towards major phreatic eruptions on 5 January 2010, 14 January 2011, 12 January 2012 and 21 May 2013 that restructured the summit morphology by adding two new vents (González et al. 2015; Alvarado et al. 2016; de Moor et al. 2016; Stix and de Moor 2018; Mick et al. 2021). After a high-frequency eruptive stage, with the first evidence of juvenile material during a major eruption on 29 October 2014 (Rizzo et al. 2017), and afterwards on 9 December 2014 and 8-13 March 2015, ash fall occurred in May 2016 in the Central Valley, evidencing the escalation into greater-scale magmatic eruptions with an impact on society. A similarly slow build-up from unrest to eruptions at Turrialba had been observed since two decades prior to the previous magmatic stage of 1864-1866 (González et al. 2015). To the day of writing,
Turrialba remains in intermittent eruptive activity, or unrest with occasional small eruptions.

This study answers to the need for a hydrogeochemical model of Irazú-Turrialba to outline future monitoring strategies. The major aim of this study is, however, to estimate if, and if so how the large Irazú-Turrialba hydrothermal system responded throughout the preand early syn-phreatic eruptive phases (2007-2012) of Turrialba's recent unrest evolution. Peculiarly, the Irazú crater lake disappeared in April 2010 after a period of steady lake-level drop since 2005, contemporaneously with the slow increase in volcanic activity of adjacent Turrialba. We will decipher whether the enhanced degassing of Turrialba during phreatic eruption unrest could have (1) affected the fluid dynamics and hydrology of the hydrothermal system located between Irazú and Turrialba volcanoes, and (2) led to the disappearance of the Irazú crater lake. Estimates of rock mass removal rates by chemical weathering will also be provided and framed in a deterministic hazard assessment regarding the stability of both volcanic edifices and phreatic activity.

\section{Geotectonic setting and eruptive history}

Irazú and Turrialba are two stratovolcanoes located at the southernmost tip of the "Cordillera Volcánica Central" in Costa Rica, caused by the subduction of the Cocos Plate beneath the Caribbean Plate (Fig. 1 inset). The stratovolcanoes are aligned roughly NE-SW (Fig. 1a), with Turrialba in a slight "behind-the-arc" setting. Both volcanoes have been constructed during the Pleistocene through the alternation of lava flows and tephras of calcalkaline basalt-andesite to (minor) dacite composition (Alvarado et al. 2006, 2016; Alvarado and Schmincke 2013; Di Piazza et al. 2015), and have been characterized by frequent phases of phreatic to strombolian activity from the summit craters in historic ages to the present (González et al. 2015; de Moor et al. 2016; Rizzo et al. 2017; Stix and de Moor 2018; Mick et al. 2021). A series of horseshoeshaped escarpments are recognized around and between the two volcanoes, suggesting that sector collapses and edifice failure have occurred recurrently in the past. Several NNW-trending faults structurally condition the northern side of Irazú and Turrialba volcanoes (Fernández et al. 1998; Pavanelli 2006). A number of secondary cones present along the southern and southwestern flanks of Irazú and Turrialba, are aligned E-W (Alvarado et al. 2006).

\section{Irazú}

The summit of Irazú $\left(9^{\circ} 59^{\prime} \mathrm{N}-83^{\circ} 51^{\prime} \mathrm{W} ; 3,432 \mathrm{~m}\right.$ a.s.l.) is made up of two craters aligned in a $\mathrm{E}-\mathrm{W}$ direction (named "Cráter Activo" and Diego de la Haya craters), located within the older "Playa Hermosa" depression 
(Alvarado et al. 2006) (Fig. 1a, b). Historic strombolian and vulcanian eruptions have occurred in 1723, 19171921 and 1963-1965 (Clark et al. 2006; Alvarado and Schmincke 2013). The 1963-1965 activity was characterized by ash dispersal towards the cities of Cartago and San José, causing ten fatalities and a substantial impact on the nation's economy (Murata et al. 1966; Alvarado 2005). The most hazardous event during that eruption was the rain-triggered lahar, running through the Río Reventado canyon on the southwest flank of Irazú, that reached Cartago (Alvarado and Schmincke 1994; Pavanelli 2006). Discussion exists whether the 8 December 1994 minor event on the northern flank of Irazú (at elevations of $3000 \mathrm{~m}$ a.s.l.) was a landslide that triggered a small ash cloud (Alvarado et al. 2013; Ulloa et al. 2013), or rather was a small phreatic eruption followed by a landslide (Mora-Amador et al. 2004), preceded by an increase in seismicity since 1992 (Ramírez et al. 2013). The northern flank of Irazú is affected by hydrothermal alteration, even manifested as highly mineralized caves with volcanospeleothems (Ulloa et al. 2013), and scarred by recurrent active rock mass movements. Boiling-temperature fumaroles appeared after the 1994 mass removal event at an elevation of about $3000 \mathrm{~m}$ a.s.l., a similar height as the floor of the Cráter Activo (Mora-Amador et al. 2004), at a $200-300 \mathrm{~m}$ horizontal distance. These fumaroles are currently active, although in 2009-2010, they had poorly defined outlets and low emission pressures.

The Cráter Activo generally hosts an emerald green crater lake (Fig. 2), which has occasionally changed its color into ochre due to overturn, i.e. mixing with ironrich bottom sediments (Ramírez et al. 2013). A steady volume decrease of the lake has been observed since 2005 (Table 1), eventually leading to its complete disappearance on 9 April 2010 (Fig. 2a-d). Afterwards, for approximately seven years, the lake has been ephemeral during periods of high rainfall. No hydrothermal activity is observed inside the Cráter Activo, and neither bubbling degassing nor water heating was observed in the crater lake before 2010. The crater lake has reappeared consistently since the 2017 rainy season. On 5 May 2019, a massive intra-crateric landslide generated an $18 \mathrm{~m}$-high wave in the crater lake (https://www.youtube.com/watch?v= wprHh9C4jZ4). Recently, weak bubbling degassing in the shallow northwest portion of the lake has been detected. The west-southwest sector of the highly altered Irazú summit area has been subjected to deformation since late 2014, passing through periods of accelerating deformation rates, with block and rock fall episodes (e.g. August 2020) (https://www.youtube.com/watch?v=HwUWp Qn7EQ4).

\section{Turrialba}

Turrialba $\left(10^{\circ} 02^{\prime} \mathrm{N}-83^{\circ} 45^{\prime} \mathrm{W} ; 3349 \mathrm{~m}\right.$ a.s.l.) has three summit craters (named Southwest, Central and Northeast craters) lined up in a NE-SW direction, and located at the southwestern end of the headwall of an elongated horse-shoe shaped, northeast-dipping sector collapse structure (Fig. 2b). Prior to the ongoing eruption, resumed on 5 January 2010, Turrialba erupted in 18641866 producing ash fall in the Central Valley of Costa Rica, and a few pyroclastic currents and lahars along the southern flanks (Reagan et al. 2006; González et al. 2015).

At Turrialba, high-pressure fumaroles were found along the northwest inner vertical wall of the Southwest crater (Murciélago fumaroles) (Fig. 3a, b). The fumarolic output has steadily increased since 2001, when a new exhalation fracture, named "Arbol Quemado", appeared between the Southwest and Central craters (Mora-Amador et al. 2004; Vaselli et al. 2009) (Fig. 3c). Turrialba has turned into a magmatic degassing system, demonstrated by the detection of $\mathrm{SO}_{2}$ in April 2004 (Vaselli et al. 2009), to culminate into renewed eruptive activity since early 2010 (Conde et al. 2014; de Moor et al. 2016; Rizzo et al. 2017; Mick et al. 2021). New fumaroles appeared in 2007 in the Arbol Quemado area (Vaselli et al. 2009) (Fig. 3c), accompanied by frequent VT seismic swarms (Martini et al. 2010). In December 2009, the Arbol Quemado fracture enlarged and manifested increased degassing. A turquoise shallow and cold lake was present in the central crater (Fig. 3d). The active Southwest crater has periodically been filled by an ephemeral shallow, cold and acidic $(\mathrm{pH}<3.5)$ lake (González et al. 2015).

\footnotetext{
(See figure on next page.)

Fig. 1 Inset: simplified map of Costa Rica with the location of Irazú and Turrialba volcanoes at the SE termination of Cordillera Central volcanic ridge. White triangles are volcanoes. The inset is a sketch of Central America geodynamics dominated by the Cocos-Caribbean subduction. a Morpho-structural sketch map of Irazú and Turrialba volcanoes, showing the main volcanic and tectonic features in the study area. The Hillside or ShadowRelieve image was elaborated by Y. Alpizar on the basis of the topographic maps 1:50,000 scale from the National Geographic Institute of Costa Rica. Symbols as in Fig. 2b. Numbered points in the figures indicate meters above sea level. b Sampling points of main fumaroles (FUM Irazù fumaroles, AQ Arbol Quemado fracture) and crater lakes (IL Irazú lake, TL Turrialba lake) in the summit of Irazú and Turrialba volcanoes, together with location of the studied thermal springs (SC San Cayetano, ST Santa Teresita, OJA Ojo de Agua, BLP Bajo Las Peñas, HBA Hervideros de Buenos Aires) and water sampling points from the rivers along the volcano flanks (white triangles). Labels of sampling points conform to the following diagrams and tables
} 


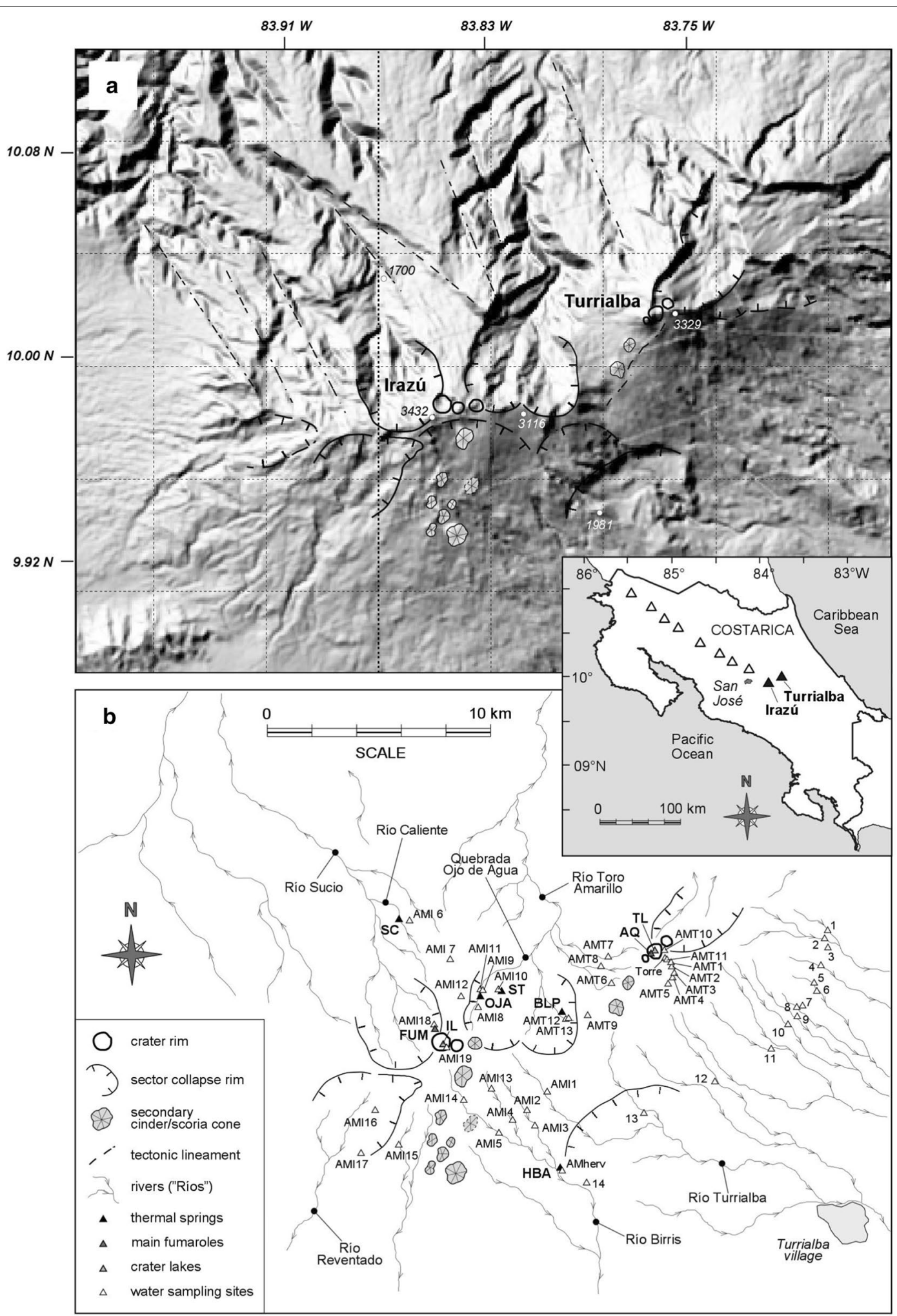

Fig. 1 (See legend on previous page.) 
The 5 January 2010 phreatic eruption opened a new vent along the inner wall of the Southwest crater (boquete 1-2010, Fig. 3c), enhancing jet-like plume degassing afterwards (Fig. 3c). Liquid sulfur poured out from the Arbol Quemado fracture on 11-12 January 2012 (González et al. 2015). Liquid sulfur flows indicate vent clearing events following heating above the melting point of sulfur $\left(119^{\circ} \mathrm{C}\right)$, causing sudden depressurization that can potentially trigger phreatic eruptions (Rouwet et al. 2017; Mora-Amador et al. 2019). In fact, a second phreatic eruption on 12 January 2012 occurred at this exact site. On 21 May 2013, ash emission occurred simultaneously from both the 2010 and 2012 vents. The 29 October 2014-May 2015 period of major phreatic to phreatomagmatic eruptions has caused a substantial enlargement of the 2012 vent area and the disappearance of the Arbol Quemado fracture along the eastern flank of Southwest crater, leading to formation of a new crater (Fig. 3d) (Alpízar et al. 2014; González et al. 2015; Rouwet et al. 2015). This phreatic phase culminated into clearly magmatic eruptions in October 2014, March 2015 and May-June and September 2016, with ash fallout in the metropolitan area.

\section{Hydrology and hydrothermal activity}

Numerous thermal springs discharge mainly from the northern flanks of Irazú and Turrialba volcanoes, at elevations between 1880 and $2430 \mathrm{~m}$ a.s.l. From west to east, they are distributed in four clusters: San Cayetano, Ojo de Agua, Santa Teresita, and Bajo Las Peñas (Fig. 1b). In this study, we initially consider the springs relative to their geographical location between Irazú and Turrialba, and not relative to their affinity with the Irazú or Turrialba geochemical dominion.

San Cayetano thermal springs are located $6 \mathrm{~km}$ north of the Irazú crater in a highly vegetated canyon, at an elevation of $1887 \mathrm{~m}$ a.s.l. The head of these springs is mixed with cold meteoric waters, whereas the main outlet discharges into a small cave-like structure cascading into a clear-blue hot pool (8-15 m large, $1.5 \mathrm{~m}$ deep; Fig. 4a). This geometry suggests that San Cayetano springs seep out of the canyon wall.

Ojo de Agua springs are located $3 \mathrm{~km}$ northeast of the Irazú crater (Fig. 1b), at an elevation of $2410 \mathrm{~m}$ a.s.l. Numerous small outlets discharge milky-white opaque waters into a network of small streams in a densely vegetated forest (Fig. 4b). The many outlets are diluted by fresh stream waters, leading to the disappearance of the white coloration within less than $1 \mathrm{~km}$ downstream. These springs seep down from the headwall.

Santa Teresita springs discharge $3.5 \mathrm{~km}$ northeast of the Irazú crater, at less than $1 \mathrm{~km}$ east of Ojo de Agua springs (Fig. 1b), into a relatively flat and extended $(\sim 1$ hectare), swampy meadowland near the Santa Teresita "lechería" (dairy farm) (Fig. 4c), at an elevation of $2241 \mathrm{~m}$ a.s.l. This geometry suggests that Santa Teresita springs are uprising from the aquifer. Spring waters are muddy and orange/red.

Bajo Las Peñas springs discharge beneath the eastern border of a large depression (Fig. 1b), at an elevation of $2426 \mathrm{~m}$ a.s.l. They consist of several vigorously evaporating dispersed outlets in a wide down-sloping meadowland ( 2 hectares). Each of these outlets is made evident by voluminous dark-red crusts precipitated around the shallow discharge area (5-10 m large). Springs are uprising from the ground.

All these thermal springs drain into two major rivers flowing northward: Río Sucio and Río Toro Amarillo (Fig. 1b). San Cayetano springs are located along the Río Caliente that converges in the main Río Sucio ("dirty river"). Río Sucio drains the hydrothermally altered, northwest sector of Irazú (Fig. 1b), and has a remarkable brown-orange color. Downstream, it converges with the clear waters of Río Hondura, $\sim 18$ km north of Irazú (Fig. 4d), in correspondence to a bridge of Highway 32, connecting the Central Valley of Costa Rica with the Caribbean coast. The easternmost springs (Ojo de Agua, Santa Teresita and Bajo Las Peñas) discharge into Río Toro Amarillo, a clear-colored river draining the northwestern side of Turrialba volcano.

The Hervideros de Buenos Aires spring group discharges at $7.5 \mathrm{~km}$ southeast of the Irazú crater, at an elevation of $1800 \mathrm{~m}$ a.s.l. (Fig. 1b). These are the only springs so far discovered along the more cultivated and inhabited south flank of Irazú. Hervideros de Buenos Aires consist of many small spring outlets discharging into a large, cold, boulder-filled, cascading river, Río Birris. The outlets show orange-red precipitates. These springs seep out of the steep headwalls of a vegetated canyon.

\section{Sampling and analytical methods}

Irazú and Turrialba fumarole condensates, thermal springs, lake and river waters were sampled in April 2007, December 2009 and May-June 2012. River and lake waters were mainly sampled in December 2009, some weeks before the first phreatic eruption of Turrialba. Temperature and $\mathrm{pH}$ were directly measured in the field. Spring waters were sampled in triplicates and stored in polyethylene bottles: $(1)$ a filtered $(0.45 \mu \mathrm{m})$ aliquot for the analysis of anions, (2) a filtered-acidified (by adding $100 \mu \mathrm{l}$ of $65 \% \mathrm{HNO}_{3}$, Suprapure) aliquot for cation analysis, and (3) an untreated aliquot for the analysis of $\mathrm{D} / \mathrm{H}$ and ${ }^{18} \mathrm{O} /{ }^{16} \mathrm{O}$. Major anionic species were analyzed by ionchromatography (DIONEX DX 120 with suppressor and conductivity detector, INGV-Palermo and a Metrohm 881 compact IC pro, UniBo). Major cationic species in 

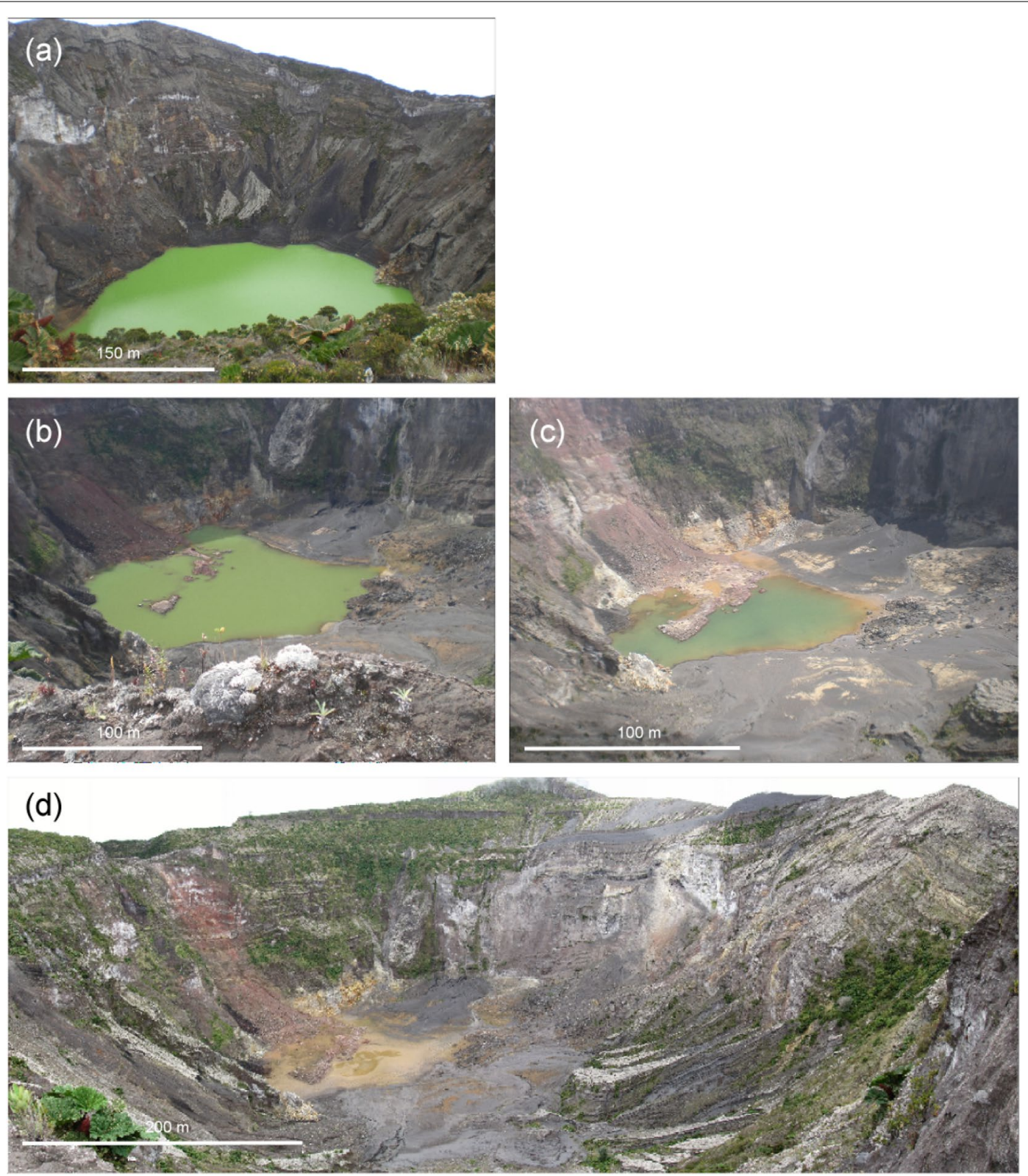

Fig. 2 View of the summit crater lake within the "Cráter Activo" of Irazú in April 2007 (a from the south), December 2009 (b from the north), March 2010 (c from the north), and May 2010 ( $d$, from the north), showing a progressive reduction of the lake level. Pictures by D. Rouwet (a, b, c) and R. Mora-Amador (d)

2007 and 2009 samples were analyzed by ion chromatography (DIONEX DX 120, INGV-Palermo), and in 2012 samples by Atomic Absorption Spectrophotometry (UniBo). The analytical precision is $\pm 5 \%$. Bicarbonate concentrations were obtained by volumetric titration with $0.01 \mathrm{~N} \mathrm{HCl}$. The $\mathrm{SiO}_{2}$ contents were measured by UV-visible spectrophotometry from diluted aliquots (Shimadzu UV-1601, INGV-Palermo). Trace elements, $\mathrm{Fe}$ and $\mathrm{Al}$ in 2007 and 2009 samples, were analyzed by
Inductively Coupled Plasma-Optical Emission Spectrometry (Horiba Jobin Yvon ULTIMA 2 ICP-OES, INGVPalermo), and in 2012 samples by Inductively Coupled Plasma-Atomic Emission Spectrometry (ICP-AES, UniBo). Electroneutrality balance of analyses is generally well below $5 \%$.

Hydrogen and oxygen isotopic compositions of fumarole condensates and spring and meteoric waters in all samples were measured by mass spectrometry 
Table 1 Level variations of Irazú crater lake: levels of the lake were measured by comparing photos taken in different times according to the method established by Rouwet (2011)

\begin{tabular}{ll}
\hline Date & Level $(\mathbf{m})$ \\
\hline April 2007 & 7.30 \\
August 2007 & 6.04 \\
February 2008 & 4.65 \\
March 2008 & 4.24 \\
April 2008 & 3.59 \\
April 2009 & 3.52 \\
December 2009 & 2.58 \\
March 2010 & 1.15 \\
April 2010 & 0.00 \\
January 2011 & 1.99 \\
March 2011 & 2.99 \\
April 2011 2011 & 2.78 \\
June 200 & 2.60 \\
\hline
\end{tabular}

(Finnigan-MAT 2253, INGV-Palermo). Analytical precisions for $\delta \mathrm{D}$ and $\delta^{18} \mathrm{O}$ are $\pm 1 \%$ and $\pm 0.1 \%$ vs V-SMOW, respectively.

\section{Results and discussion \\ The origin of thermal waters: $\delta D$ and $\delta^{18} O$}

The $\delta \mathrm{D}$ and $\delta^{18} \mathrm{O}$ isotopic compositions of thermal springs, crater lakes, fumarole condensates are reported in Table 2, and illustrated in Fig. 5. The chemical and isotopic compositions of Irazú and Turrialba meteoric water are presented in Tables 3 and 4, respectively. Meteoric water (MW hereafter) and andesitic water [AW hereafter; Taran et al. (1989)] are generally the two possible water end members in magmatic-hydrothermal systems. The thermal spring, lake waters and MW have isotopic compositions that plot slightly left of the Global Meteoric Water Line (GMWL, Fig. 5), corresponding the local meteoric water lines of Irazú and Turrialba (IMWL-blue and TMWL-gray, respectively, defined by 57 isotopic
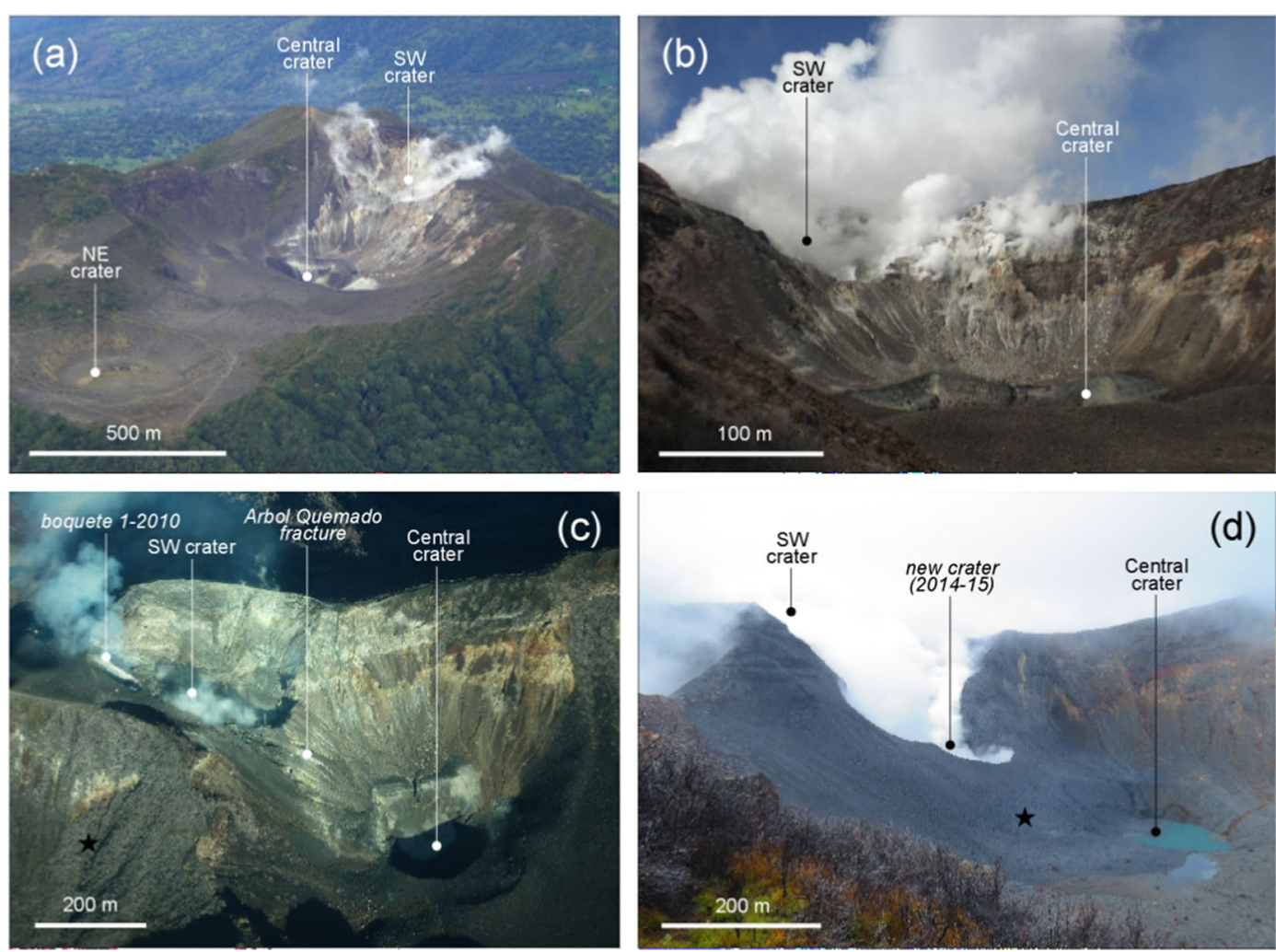

Fig. 3 Representative images of the exhalative and eruptive activity of the summit craters of Turrialba from 2007 to present times. a View from the north in April 2007 with a diffuse fumarolic degassing from the SW crater. b View from the east in December 2009 showing an increased gas discharge from the SW crater. c Aerial view in 2011 showing the location of "boquete 1-2010" vent and Arbol Quemado fracture along the flanks of SW crater. Note to the south (black star) the burned native mountain forest due to acidic rains related to gas emission from the "boquete 1-2010" vent. $\mathbf{d}$ View from the east in December 2014 of the new crater opened along the flank between the SW and Central craters of Turrialba during the latest eruptive cycle (ongoing at the moment of writing). Note the substantial thickness of ash and blocks related to this eruptive cycle largely covering the flanks of Central crater (black star), which is filled by an ephemeral lake. Pictures by R. Mora-Amador (a, d), D. Rouwet (b) and G. González-llama (c) 

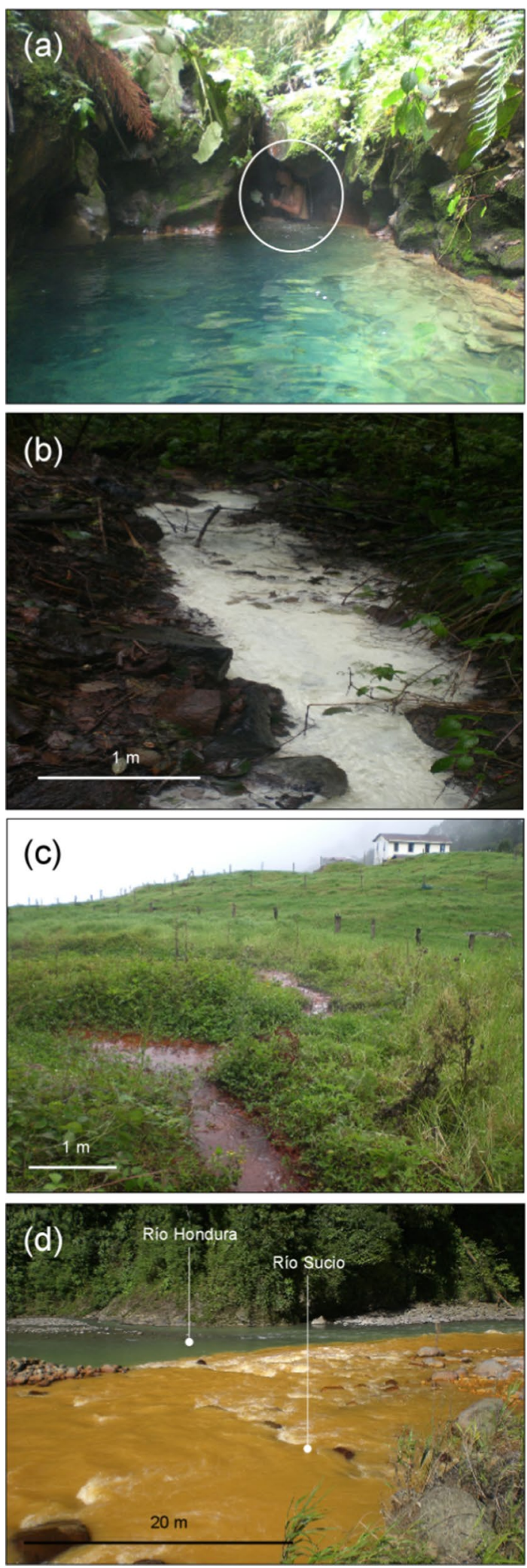

4 Fig. 4 a San Cayetano thermal spring discharging into a blue-colored pool from a cave-like structure (in April 2007). Mind the person in the circle for scale. b Ojo de Agua thermal springs discharging well-known milky-white waters (in December 2009). c Santa Teresita thermal springs discharging red-brown waters into a flat meadowland near the"lechería" site (in December 2009). d View of the Río Sucio river with its peculiar brown-orange waters converging with the clear waters of Río Hondura river 18 km north of Irazú volcano (in December 2009). Pictures by D. Rouwet

compositions of MW, Tables 3 and 4). Despite the fact that the IMWL and TMWL show a practically overlapping trend, the isotopic composition of Turrialba MW varies in a narrower range $(-20$ to $-50 \%$ ), if compared to Irazú MW (0 to $-80 \%$ ) (Fig. 5) The Turrialba crater lake water has significantly higher $\delta^{18} \mathrm{O}$ and $\delta \mathrm{D}$ values $(-4.1 \%$ and $-20 \%$, respectively), suggesting that the lake water evaporated at high relative humidity at close to ambient temperatures. Only when the lake water temperature is substantially above average ambient temperatures and/or the relative humidity is well below 1, the evaporation line of lake water will have a much 'flatter' slope than the local MWL (e.g., Varekamp and Kreulen 2000). The $d 18 \mathrm{O}$ and $\mathrm{dD}$ isotopic composition of Irazú crater lake $(-8.7 \%$ and -48 , respectively) shows a similar trend, but within the lower isotopic MW composition for Irazú.

The Turrialba fumarole condensate (Arbol Quemado, $\mathrm{AQ}$ ) is the only fluid that deviates from the meteoric composition (Fig. 5): the higher $\delta^{18} \mathrm{O}$ values $(-6.9 \%$ ) could be due to enhanced water-rock interaction at higher temperature within the aquifer feeding the fumaroles. There is no clear evidence of contribution of the AW end member.

Figure 6 relates $\delta \mathrm{D}$ with the elevation (a) and longitude (b) to investigate the effects of altitude and geographic position on the isotopic composition of waters discharging from both volcanoes. $\delta \mathrm{D}$ (and $\delta^{18} \mathrm{O}$, not shown) shows a wider range and reaches lower values for MW at higher altitude; the isotopic "rain out" effect by Rayleigh fractionation during rainfall going uphill outweighs the opposite isotopic fractionation effect due to rainfall at lower temperatures (i.e. higher elevations) (Fig. 6a). Although the water samples are taken from similar elevations for both volcanoes, waters from Turrialba have a more homogeneous and on average heavier isotopic composition. This is especially evident for samples above $2000 \mathrm{~m}$ a.s.l. (Fig. 6a). The isotopic composition below $2000 \mathrm{~m}$ a.s.l. homogenizes for both volcanoes, probably because the flanks at lower elevations are practically always covered by clouds formed by reevaporation and evapotranspiration from the forest (Holwerda et al. 2010; Bruijnzeel et al. 2011; Goldsmith et al. 
2011; Muñoz-Villers et al. 2012), or, alternatively, rivers at lower elevations discharge the average MW after infiltration in the volcanic edifices.

Both volcanoes are affected at high elevations by rains transported by trade winds, arriving from the Caribbean. The slightly heavier and more homogeneous isotopic signature for the more eastward Turrialba is interpreted to derive from rains that enter Costa Rica from the northnortheast-east. Rains falling on Irazú, instead located in the rain shadow of Turrialba, are therefore isotopically lighter (Fig. 6b). Figure 6b hence explains the different local MW compositions of Irazú and Turrialba, although there best fit lines in Fig. 5 still almost coincide. The "rain shadow principle" as well counts for the thermal springs, as they are fed by MW within the rain shadow, west of Turrialba. Even the Bajo Las Peñas springs, closer to Turrialba, have a more "Irazú-like" signature. Their slightly higher $\delta \mathrm{D}$ can result from evaporation (Fig. 6a), given their higher temperature (up to $68^{\circ} \mathrm{C}$ ).

Peculiarly, the $\delta \mathrm{D}$ values for the Irazú crater lake at $3000 \mathrm{~m}$ a.s.l. are similar (near $-60 \%$, Fig. 6a) to those for San Cayetano, Santa Teresita, Ojo de Agua, and Hervideros de Buenos Aires springs (1880-2430 m a.s.l.). As the lake water is in equilibrium with the air temperature, isotopic enrichment of crater lake water by evaporation is practically excluded, especially given the highly humid conditions. If considering the Irazú crater lake as the meteoric end member of the summit area, this isotopic similarity suggests an infiltration from the summit area towards the springs at lower elevations (Rouwet et al. 2009; and references therein).

\section{Major elements}

The temperature, $\mathrm{pH}$ and major, minor and trace element compositions of thermal springs and crater lake waters are presented in Tables 2 and 5. In Fig. 7, Santa Teresita thermal spring waters show high total dissolved solids (TDS hereafter, 2652-2874 mg/L, Table 2) compared to their relatively low temperatures $\left(35^{\circ} \mathrm{C}\right)$. On the contrary, Bajo Las Peñas thermal spring waters are characterized by high temperature (up to $68{ }^{\circ} \mathrm{C}$ ) and low TDS (411$558 \mathrm{mg} / \mathrm{L}$; Table 2). San Cayetano springs have high TDS (approximately $1950 \mathrm{mg} / \mathrm{L}$ ) and an intermediate temperature $\left(\sim 36^{\circ} \mathrm{C}\right)$. The remaining thermal springs, Ojo de Agua and Hervideros de Buenos Aires, have intermediate TDS and temperature values (Fig. 7). The crater lakes of Irazú and Turrialba have similar temperatures $\left(13^{\circ} \mathrm{C}\right.$ and $15{ }^{\circ} \mathrm{C}$, respectively, near ambient air temperatures at this elevation) and TDS $(800 \mathrm{mg} / \mathrm{L}$ and $950 \mathrm{mg} / \mathrm{L}$, respectively, Fig. 7).

Mixing plots between $\mathrm{Cl}$ and major cations indicate that all the thermal springs and crater lakes are mixtures of meteoric and hydrothermal end members (Fig. 8). All the springs clearly have different $\mathrm{Cl}$-cation trends, suggesting no common hydrothermal end member for any of the springs. Hervideros de Buenos Aires and Bajo Las Peñas thermal springs have the lowest $\mathrm{Cl}$ contents (Fig. 8) and show a similar mixing trend. Nevertheless, their geographic position on opposite flanks of Irazú inhibits them from having a common hydrothermal end member. Santa Teresita has the highest $\mathrm{Ca}$ and $\mathrm{Mg}$ concentrations (588-687 and 81-83 mg/L, Fig. 8a, b, respectively), but relatively low $\mathrm{Na}$ and $\mathrm{K}$ concentrations (34-40 and 9-11 mg/L, Fig. 8c, d, respectively), which decrease with increasing $\mathrm{Cl}$ contents. San Cayetano thermal springs display the highest $\mathrm{Cl}$ concentrations (from 197 to $239 \mathrm{mg} / \mathrm{L}$, Fig. 8), in agreement with their low $\mathrm{pH}$ (2.6-3.0).

Multi-trends are also observed for $\mathrm{SO}_{4}$ versus $\mathrm{Cl}$ concentrations (Fig. 9a). Santa Teresita and San Cayetano show the highest $\mathrm{SO}_{4}$ concentrations $(1039 \mathrm{mg} / \mathrm{L}$ and $1785 \mathrm{mg} / \mathrm{L}$, respectively). The low-Cl waters are classical steam-heated waters, originating by near-surface oxidation of $\mathrm{H}_{2} \mathrm{~S}$ (Taran and Kalacheva 2020, and references therein). The $\mathrm{SO}_{4} / \mathrm{Cl}$ molar ratios for San Cayetano waters are notably lower with respect to other spring waters (1.5-1.7) due to the higher $\mathrm{Cl}$ contents. Their $\mathrm{SO}_{4} /$ $\mathrm{Cl}$ ratios remain stable through the period of observation (2007-2012, Table 2, Fig. 9a). Together with their high acidity, this suggests an Acid-Sulfate-Chloride (ASC) type for San Cayetano water, probably originating from (1) near-surface mixing of steam-heated $\mathrm{SO}_{4}$-rich waters with a deep $\mathrm{Na}$-Cl-type "geothermal" water, and/or (2) interaction of $\mathrm{Na}$-Cl-type waters with rocks that underwent argillic and advanced argillic alteration processes, as recently reviewed by Taran and Kalacheva (2020) for ASC waters globally, and/or (3) a direct contribution of $\mathrm{HCl}$ degassing for these springs. As an intermediate conclusion, we can say that the San Cayetano springs are the only springs that testify a deeper origin.

Calcium and $\mathrm{SO}_{4}$ account for $90-95 \%$ of TDS at the Santa Teresita spring (Fig. 7, Table 2). The $\mathrm{Cl}_{-} \mathrm{SO}_{4}$ trend line for Santa Teresita (Fig. 9a) intercepts the vertical axis at $\sim 1600 \mathrm{mg} / \mathrm{L}$ of $\mathrm{SO}_{4}$, suggesting that $\mathrm{MW}$ is enriched in $\mathrm{Ca}$ and $\mathrm{SO}_{4}$ prior to mixing. In Fig. 9b, Santa Teresita, Hervideros de Buenos Aires, Bajo Las Peñas springs and the Irazú crater lake plot close to the "anhydrite line" (1/1 $\mathrm{Ca}-\mathrm{SO}_{4}$ molar proportions), suggesting that the original MW has dissolved anhydrite or gypsum (Fig. 9b). A right shift from the "anhydrite line", observed to more or less extent for all spring and lake waters, states a $\mathrm{SO}_{4}$ excess with respect to the anhydrite equilibrium, probably caused by the absorption and near-surface oxidation of $\mathrm{H}_{2} \mathrm{~S}$ (i.e. steam-heated waters) (Taran and Kalacheva 2020, and references therein). This effect is largest for the 


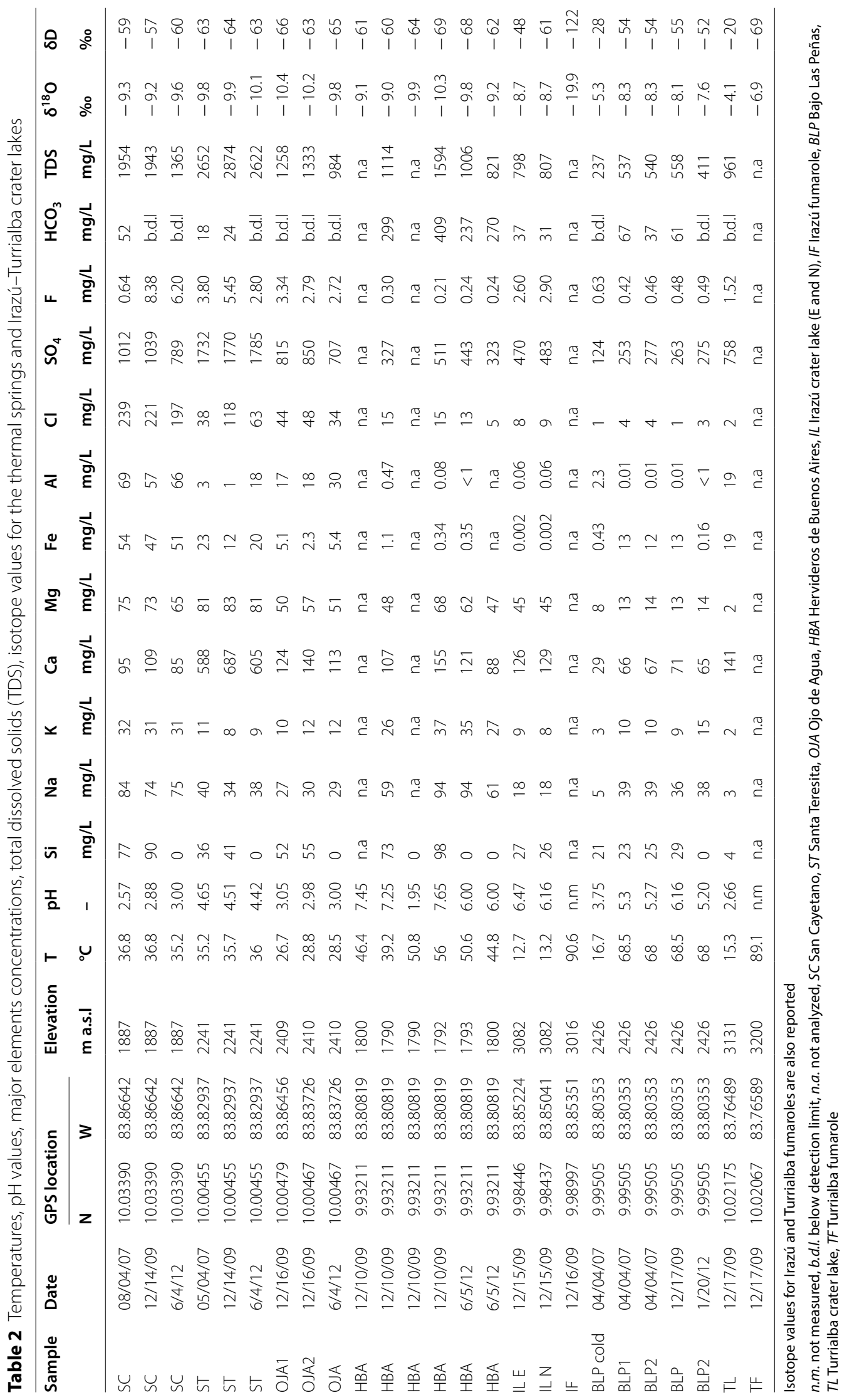




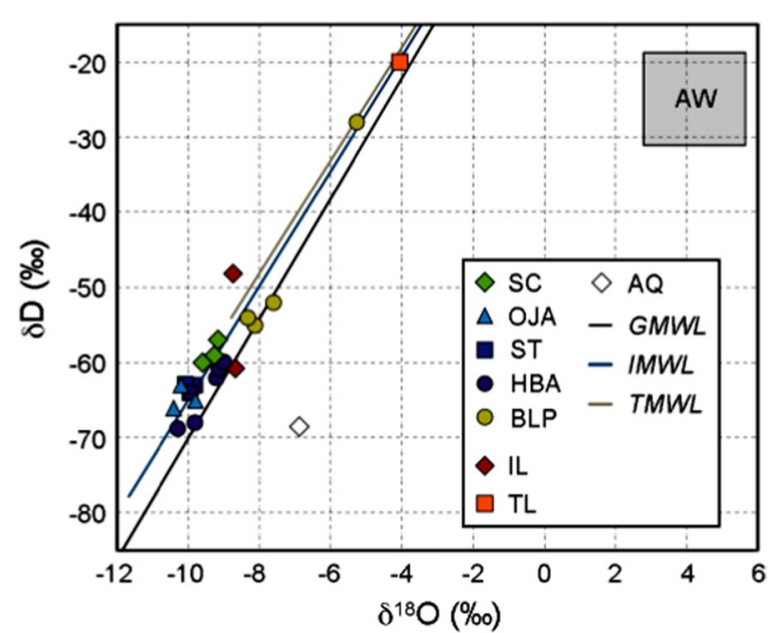

Fig. $5 \delta^{18} \mathrm{O}$ vs $\delta D$ for the thermal springs and Irazú-Turrialba lake waters compared with meteoric waters (GMWL global meteoric water line, IMWL Irazú meteoric water line, TMWL Turrialba meteoric water line) and fumaroles ( $A Q$ Arbol Quemado). Values for the Irazú fumarole are out of scale $\left(\delta^{18} \mathrm{O}=-19.9 \%\right.$, $\left.\delta \mathrm{D}=-122 \%\right)$. The "andesitic water" end-member (AW) is also illustrated

Turrialba crater lake, and the San Cayetano and Ojo de Agua springs, also the most acidic waters of this study.

\section{Minor and trace elements}

Minor and trace element compositions of thermal springs and crater lakes are presented in Table 5, and compared with those of Irazú and Turrialba rocks in Fig. 10. Turrialba and Irazú rocks have similar chemical compositions (Di Piazza et al. 2015). These rock types have a density of $2800 \mathrm{~kg} / \mathrm{m}^{3}$ (to be used below).

Information on the relative mobility of elements is given by ratios indicating the amount of water needed to dissolve a gram of each specific element in the rock [numbers along diagonal lines in Fig. 10; a similar approach as the "rock versus water plots" by Taran et al. (2008), and "isosol plots" by Varekamp (2015)]. Elements with a higher solubility have a lower ratio, which means that less water is needed to dissolve a certain amount of the given element from the rock, and keep it in solution. Major elements hence align along the lines of low ratios for all the thermal springs and Irazú rocks (Fig. 10). Element mobility also depends on $\mathrm{pH}$ : more acidic waters leach rocks more easily.

$\mathrm{Fe}$ and $\mathrm{Al}$ align along high ratio lines in the Bajo Las Peñas springs (only Al; Fig. 10a) and Irazú crater lake (Fig. 10b): due to their higher $\mathrm{pH}$ (from 5.2 to >6) Fe and $\mathrm{Al}$ can be lost from solution by precipitation. The Irazú crater lake has the highest water-rock ratios for being the least acidic, together with Hervideros de Buenos Aires springs (not shown in Fig. 10; see Table 2). Ojo de Agua (not shown) and San Cayetano springs (Fig. 10c) tend to retain $\mathrm{Fe}$ and $\mathrm{Al}$ in solution more easily due to their lower $\mathrm{pH}(2-3)$. Santa Teresita spring waters only partially retain Fe in solution (Fig. 10d), being less acid ( $\mathrm{pH}$ from 4.42 to 4.65) with respect to Ojo de Agua and San Cayetano. Superficial precipitation of Fe oxides is evident (Fig. 4c). Mn, Li, Sr are the most soluble minor elements for all the thermal springs, as shown by their low ratios (between $10^{2}$ and $10^{4}$; Fig. 10). Instead, $\mathrm{Cu}$ and $\mathrm{Ba}$ represent the highest ratios (between $10^{5}$ and $10^{6}$; Fig. 10). Loss of $\mathrm{Cu}$ from solution in a steam-heated hydrothermal system can occur by sulfide formation. Barium precipitates as barite $\left[\mathrm{BaSO}_{4}\right]$.

\section{Mineral solubility and geothermometry}

Chemical compositions of thermal springs and crater lakes reflect those of Irazú-Turrialba rocks, indicating dissolution of the wall rock. This effect is strongly enhanced for the more acidic waters (San Cayetano and Ojo de Agua). All Irazú-Turrialba thermal springs and crater lakes are "immature" waters inhibiting the application of classical geothermometry (Giggenbach 1988; Chiodini et al. 2014; Romano and Liotta 2018). Alternatively, temperatures of the geothermal reservoirs are estimated based on the SI (Saturation Index) of minerals for a temperature range (Fig. 11) (Pang and Reed 1998; Taran et al. 2008):

$$
\mathrm{SI}=\log (\mathrm{IAP} / K)
$$

where IAP is the product of the measured concentrations of the ions in solution that make up the mineral of interest written in the stoichiometry of the reaction for which the $K$ value (i.e. solubility product) is calculated, at a given temperature. Values of $\mathrm{SI}>0$ indicate oversaturation, whereas $\mathrm{SI}<0$ indicates under-saturation of the given mineral. SIs are calculated using the PHREEQC software (Parkhurst and Appelo 1999) in a temperature range from 25 to $275{ }^{\circ} \mathrm{C}$, for steps of $50{ }^{\circ} \mathrm{C}$ (Reed 1982; Pang and Reed 1998; Palandri and Reed 2001; Taran et al. 2008) at atmospheric pressure conditions. The results are plotted in Fig. 11, which can be considered an alternative geothermometry graph (Pang and Reed 1998). Silica phases (chalcedony and quartz) appear saturated at $\sim 100{ }^{\circ} \mathrm{C}$, hence buffered by boiling processes inside the reservoirs. Alunite, instead, is supersaturated at near-outlet spring temperatures. Equilibrium $(\mathrm{SI} \sim 0)$ is obtained for anhydrite $\left(\mathrm{CaSO}_{4}\right)$, a mineral with a reverse solubility (i.e. less soluble at higher $T$ ), at different temperatures for 
Table 3 Temperature, chemical $\left(\mathrm{pH}_{1} \mathrm{Cl}, \mathrm{SO}_{4}\right)$ and isotope values of meteoric waters (AM), rivers and cold springs for Irazú (I)

\begin{tabular}{|c|c|c|c|c|c|c|c|c|c|c|c|}
\hline \multirow[t]{2}{*}{ Sample } & \multirow[t]{2}{*}{ Date } & \multicolumn{2}{|c|}{ GPS location } & \multirow{2}{*}{$\begin{array}{l}\text { Elevation } \\
\text { m a.s.I }\end{array}$} & \multirow{2}{*}{$\begin{array}{l}\mathrm{T} \\
{ }^{\circ} \mathrm{C}\end{array}$} & \multirow{2}{*}{$\begin{array}{l}\mathrm{pH} \\
-\end{array}$} & \multirow{2}{*}{$\begin{array}{l}\mathrm{Cl} \\
\mathrm{mg} / \mathrm{L}\end{array}$} & \multirow{2}{*}{$\begin{array}{l}\mathrm{SO}_{4} \\
\mathrm{mg} / \mathrm{L}\end{array}$} & \multirow{2}{*}{$\begin{array}{l}\delta^{18} O \\
\% \text { o }\end{array}$} & \multirow{2}{*}{$\begin{array}{l}\delta D \\
\% o\end{array}$} & \multirow{2}{*}{$\begin{array}{l}\mathrm{Q} \\
\mathrm{kg} / \mathrm{s}\end{array}$} \\
\hline & & $\mathbf{N}$ & w & & & & & & & & \\
\hline AMI1 & $12 / 11 / 09$ & 9.96339 & 83.81147 & 2623 & 15.3 & $n \cdot m$ & 4 & 6 & -4.1 & -18 & 1 \\
\hline AMI2 & 12/11/09 & 9.95495 & 83.82019 & 2512 & 13.4 & n.m & 5 & 4 & -3.6 & -14 & 1 \\
\hline AMI3 & 12/11/09 & 9.94709 & 83.81990 & 2357 & 15.7 & n.m & 0 & 4 & -8.6 & -58 & 2 \\
\hline AMI4 & $12 / 11 / 09$ & 9.95181 & 83.82502 & 2489 & 13.2 & $n \cdot m$ & 10 & 14 & -8.6 & -54 & 3 \\
\hline AMI5 & $12 / 11 / 09$ & 9.94699 & 83.83091 & 2397 & 13.7 & $n \cdot m$ & 9 & 49 & -10.5 & -69 & 12 \\
\hline AMI6 & 12/14/09 & 10.03367 & 83.86285 & 1916 & 17.9 & $n \cdot m$ & 8 & 97 & -7.9 & -49 & n.m \\
\hline AMI7 & $12 / 14 / 09$ & 10.01621 & 83.84826 & 2336 & 13.1 & n.m & 17 & 14 & -6.8 & -39 & 1 \\
\hline AMI8 & 12/14/09 & 10.00655 & 83.83698 & 2348 & 14.8 & n.m & 7 & 109 & -9.5 & -59 & 1 \\
\hline AMI9 & 12/14/09 & 10.00531 & 83.83605 & 2347 & 19.5 & n.m & 21 & 529 & -9.8 & -60 & 1 \\
\hline AMI10 & 12/14/09 & 10.00455 & 83.82937 & 2336 & 12.9 & n.m & 3 & 239 & -8.9 & -55 & 1 \\
\hline AMI11 & $12 / 14 / 09$ & 10.00462 & 83.83554 & 2354 & 14.6 & $\mathrm{n} \cdot \mathrm{m}$ & 14 & 50 & -4.1 & -17 & 0.5 \\
\hline AMI12 & $12 / 14 / 09$ & 10.00044 & 83.84297 & 2759 & 11.2 & $\mathrm{n} \cdot \mathrm{m}$ & 8 & 10 & -7.0 & -37 & 0.5 \\
\hline AMI13 & $12 / 14 / 09$ & 9.96382 & 83.83516 & 2969 & 12.2 & $\mathrm{n} \cdot \mathrm{m}$ & 4 & 18 & -5.8 & -32 & 1 \\
\hline AMI14 & $12 / 14 / 09$ & 9.96059 & 83.84438 & 2888 & 11.8 & n.m & 7 & 34 & -11.1 & -76 & 1 \\
\hline AMI15 & $12 / 14 / 09$ & 9.94488 & 83.86962 & 2478 & 13.4 & n.m & 8 & 29 & -11.7 & -82 & 3 \\
\hline AMI16 & 12/15/09 & 9.96065 & 83.87814 & 2769 & 12.6 & n.m & 3 & 32 & -11.7 & -78 & $n \cdot m$ \\
\hline AMI17 & 12/15/09 & 9.94215 & 83.88493 & 2420 & 14.6 & n.m & 8 & b.d.l & -11.7 & -80 & 30 \\
\hline AMI18 & 12/16/09 & 9.99008 & 83.85372 & 2997 & n.m & n.m & 0 & 1281 & -0.1 & 2 & n.m \\
\hline 14 & $12 / 10 / 09$ & 9.92398 & 83.79650 & 1612 & 19.6 & n.m & 3 & 13 & -7.6 & -44 & 100 \\
\hline AM HBA & 12/10/09 & 9.93108 & 83.80825 & 1835 & n.m & n.m & 7 & 2 & -7.4 & -47 & n.m \\
\hline Río Birris HBA & 12/10/09 & 9.93211 & 83.80819 & 1792 & 18 & n.m & 4 & 27 & -9.0 & -60 & n.m \\
\hline Río Caliente SC & 12/14/09 & 10.04027 & 83.86959 & 1887 & 29.6 & n.m & 220 & 922 & -8.8 & -55 & 110 \\
\hline Rio Sucio & 12/18/09 & 10.14812 & 83.94936 & 475 & 17.1 & 3.14 & 28 & 445 & -6.1 & -34 & 228 \\
\hline Río Hondura & 12/18/09 & 10.14739 & 83.95020 & 478 & 13.8 & 7.03 & 0 & 42 & -5.9 & -32 & n.m \\
\hline SC cold up & 12/14/09 & 10.03390 & 83.86642 & 1887 & n.m & n.m & 6 & 21 & -4.8 & -25 & n.m \\
\hline SC cold springs & 08/04/07 & 10.03390 & 83.86642 & 1887 & 15.3 & 6.98 & 2 & 23 & -5.3 & -28 & n.m \\
\hline SC waterfall & $12 / 14 / 09$ & 10.03394 & 83.86219 & 1860 & n.m & n.m & 220 & 977 & -9.2 & -57 & n.m \\
\hline
\end{tabular}

Meteoric water values are generally assumed as corresponding to the rivers (Ríos and Quebradas), for which the average water discharges are reported. HBA and SC as in Table 2

n.m. not measured

the different springs. If we assume that anhydrite is present as precipitates in the reservoir, the $\mathrm{SI}=0$ condition can provide useful geothermometric temperature estimates for the thermal springs: $\sim 200-230{ }^{\circ} \mathrm{C}$ for San Cayetano (Fig. 11a), 110-140 ${ }^{\circ} \mathrm{C}$ for Ojo de Agua (Fig. 11b) and Hervideros de Buenos Aires (Fig. 11c), $135-165^{\circ} \mathrm{C}$ for Bajo Las Peñas (Fig. 11d), $\sim 50-80{ }^{\circ} \mathrm{C}$ for Santa Teresita (Fig. 11e). San Cayetano has the highest geothermometric temperatures, suggesting that it is linked to a deeper hydrothermal system, in agreement with its ASC composition (Taran and Kalacheva 2020). On the contrary, Santa Teresita is nearly equilibrated at the spring outlet temperature (about $36{ }^{\circ} \mathrm{C}$ versus $50-80{ }^{\circ} \mathrm{C}$ ), which probably results from the near-surface mixing with the anhydrite-enriched cooler meteoric water (Fig. 9b).

Fe minerals (hematite and goethite) precipitate at the spring temperature at Hervideros de Buenos Aires, Bajo
Las Peñas and Santa Teresita (Fig. 11c-e), which are the less acidic springs (Table 2). This mineral assemblage explains why these three thermal spring outlets have brownish orange to reddish colors. For the more acidic springs, San Cayetano, Ojo de Agua and Santa Teresita, alunite is highly supersaturated (Fig. 11a, b and e). The lower-pH San Cayetano and Ojo de Agua waters do not show precipitation of $\mathrm{Fe}$ - and $\mathrm{Al}$-oxyhodroxides, and thus, San Cayetano water is blueish (Fig. 4a) and Ojo de Agua discharges milky-white waters (Fig. 4b) (related to silica-saturation or colloidal sulfur). Regarding the Irazú crater lake, the SI of some minerals is near-zero at the lake temperature $\left(13{ }^{\circ} \mathrm{C}\right)$, except for anhydrite which is highly under-saturated. 
Table 4 Temperature, chemical $\left(\mathrm{pH}_{1} \mathrm{Cl}, \mathrm{SO}_{4}\right)$ and isotope values of meteoric waters (AM), rivers and cold springs for Turrialba (T)

\begin{tabular}{|c|c|c|c|c|c|c|c|c|c|c|c|}
\hline \multirow[t]{2}{*}{ Sample } & \multirow[t]{2}{*}{ Date } & \multicolumn{2}{|c|}{ GPS location } & \multirow{2}{*}{$\begin{array}{l}\text { Elevation } \\
\mathrm{m} \text { a.s.I }\end{array}$} & \multirow{2}{*}{$\begin{array}{l}\mathrm{T} \\
{ }^{\circ} \mathrm{C}\end{array}$} & \multirow[t]{2}{*}{$\mathrm{pH}$} & \multirow{2}{*}{$\begin{array}{l}\mathrm{Cl} \\
\mathrm{mg} / \mathrm{L}\end{array}$} & \multirow{2}{*}{$\begin{array}{l}\mathrm{SO}_{4} \\
\mathrm{mg} / \mathrm{L}\end{array}$} & \multirow{2}{*}{$\begin{array}{l}\delta^{18} \mathrm{O} \\
\% \text { o }\end{array}$} & \multirow{2}{*}{$\begin{array}{l}\delta \mathrm{D} \\
\% o\end{array}$} & \multirow{2}{*}{$\begin{array}{l}\mathrm{Q} \\
\mathrm{kg} / \mathrm{s}\end{array}$} \\
\hline & & $\mathbf{N}$ & w & & & & & & & & \\
\hline AMT1 & $12 / 11 / 09$ & 10.01677 & 83.76029 & 3128 & n.m & n.m & 2 & 10 & -8.8 & -51 & n.m \\
\hline AMT2 & $12 / 11 / 09$ & 10.01470 & 83.75984 & 3055 & 16.9 & n.m & 3 & 6 & -6.3 & -36 & n.m \\
\hline AMT3 & $12 / 11 / 09$ & 10.01369 & 83.75849 & 3012 & 11.2 & n.m & 13 & 15 & -7.5 & -44 & n.m \\
\hline AMT4 & $12 / 11 / 09$ & 10.01204 & 83.75922 & 2951 & 11.7 & n.m & 7 & 12 & -7.1 & -42 & n.m \\
\hline AMT5 & $12 / 11 / 09$ & 10.00680 & 83.77022 & 2811 & 14.4 & n.m & 7 & 19 & -6.9 & -41 & n.m \\
\hline AMT6 & $12 / 11 / 09$ & 10.00652 & 83.78184 & 2710 & 14.6 & n.m & 16 & 7 & -4.6 & -23 & n.m \\
\hline AMT7 & $12 / 11 / 09$ & 10.01720 & 83.78367 & 2777 & 14.9 & n.m & 105 & 180 & -6.2 & -37 & 3 \\
\hline AMT8 & $12 / 11 / 09$ & 10.01378 & 83.78590 & 2658 & 14.3 & n.m & 46 & 54 & -5.9 & -32 & 0.5 \\
\hline AMT9 & $12 / 11 / 09$ & 9.99276 & 83.79401 & 2700 & 11.6 & n.m & 0 & 4 & -7.4 & -42 & 3 \\
\hline AMT10 & 12/17/09 & 10.02206 & 83.76480 & 3154 & n.m & n.m & 0 & 19 & -2.3 & n.a & n.m \\
\hline Torre & 04/04/07 & 10.01976 & 83.76188 & 3300 & 10 & 6.28 & 2 & 10 & -8.8 & -55 & n.m \\
\hline AMT11 & $12 / 17 / 09$ & 10.01988 & 83.76188 & 3280 & 9.1 & n.m & 15 & 26 & -7.9 & -47 & n.m \\
\hline AMT12 & 12/17/09 & 9.99505 & 83.80353 & 2427 & 14.9 & n.m & 2 & 91 & -7.2 & -41 & 1 \\
\hline AMT13 & 12/17/09 & 9.99169 & 83.80166 & 2570 & 11.7 & n.m & b.d.l & 3 & -7.4 & -44 & 5 \\
\hline 1 & 12/10/09 & 10.02322 & 83.69270 & 1403 & 15.6 & n.m & b.d.l & 1 & -6.2 & -32 & 100 \\
\hline 2 & 12/10/09 & 10.02181 & 83.69302 & 1402 & 19.7 & n.m & 7 & b.d.l & -4.7 & -23 & 2 \\
\hline 3 & 12/10/09 & 10.01683 & 83.69242 & 1414 & 16.7 & n.m & b.d.l & b.d.l & -5.0 & -25 & 4 \\
\hline 4 & 12/10/09 & 10.01140 & 83.69480 & 1453 & 17.2 & n.m & b.d.l & b.d.l & -5.3 & -25 & 20 \\
\hline 5 & 12/10/09 & 10.00433 & 83.69822 & 1473 & 17.3 & n.m & b.d.l & b.d.l & -5.2 & -26 & 4 \\
\hline 6 & 12/10/09 & 10.00259 & 83.69944 & 1494 & 17.9 & n.m & b.d.l & b.d.l & -6.0 & -34 & 8 \\
\hline 7 & 12/10/09 & 9.99712 & 83.70167 & 1450 & 17.8 & n.m & b.d.l & b.d.l & -5.2 & -29 & 12 \\
\hline 8 & 12/10/09 & 9.99399 & 83.70126 & 1434 & 17.2 & $n \cdot m$ & b.d.l & b.d.l & -5.9 & -32 & 7 \\
\hline 9 & 12/10/09 & 9.99246 & 83.70542 & 1426 & 17.4 & $n \cdot m$ & b.d.l & b.d.l & -6.0 & -32 & 25 \\
\hline 10 & 12/10/09 & 9.99020 & 83.70921 & 1442 & 17.7 & n.m & b.d.l & b.d.l & -6.1 & -34 & 30 \\
\hline 11 & 12/10/09 & 9.98050 & 83.71943 & 1418 & 18.1 & n.m & 6 & 8 & -6.6 & -37 & 30 \\
\hline 12 & 12/10/09 & 9.97020 & 83.74058 & 1477 & 16.8 & n.m & b.d.l & 2 & -7.3 & -44 & 40 \\
\hline 13 & 12/10/09 & 9.95647 & 83.77288 & 1647 & 15.7 & n.m & b.d.l & 6 & -8.1 & -50 & 35 \\
\hline Rio Toro Amarillo & $12 / 18 / 08$ & 10.19695 & 83.81815 & 314 & 14.2 & 7.13 & 7 & 95 & -6.1 & -33 & 228 \\
\hline Rio Blanco & $12 / 18 / 09$ & 10.21406 & 83.84227 & 263 & 18 & n.m & b.d.l & b.d.l & -5.1 & -25 & n.m \\
\hline Rio Corinto & 12/18/09 & 10.21324 & 83.88755 & 233 & 16.7 & n.m & b.d.l & b.d.l & -4.9 & -23 & n.m \\
\hline
\end{tabular}

Meteoric water values are generally assumed as corresponding to the rivers (Ríos and Quebradas), for which the average water discharges are reported. HBA and SC as in Table 2

n.m. not measured

\section{Water mass budget for thermal springs}

We estimate the water mass budget for the Irazú and Turrialba volcanoes by comparing the water loss by thermal spring discharges with the vapor loss by plume degassing (next section). In the field it is often impossible to directly measure flow rates from springs. Alternatively, thermal spring discharges can be estimated using the discharges of rivers considering their respective $\mathrm{Cl}$ or $\mathrm{SO}_{4}$ contents, according to:

$$
\mathrm{Qr} * \mathrm{Cr}=\mathrm{Qs} * \mathrm{Cs}
$$

where Qr and Qs are the discharges of rivers and thermal springs, respectively (in $\mathrm{L} / \mathrm{s}$ ); and $\mathrm{Cr}$ and $\mathrm{Cs}$ are the $\mathrm{Cl}$ or $\mathrm{SO}_{4}$ concentrations of rivers and thermal spring waters, respectively (in $\mathrm{mg} / \mathrm{L}$ ). This approach is based on the "Cl-inventory method" (Ingebritsen et al. 2001; Taran and Peiffer 2009; Chiodini et al. 2014; Collard et al. 2014; Rouwet et al. 2014a). Sulfate is used here, instead of the more conservative $\mathrm{Cl}$, because the generally low concentrations of $\mathrm{Cl}$ could introduce a high error in the flux estimates. Hence, the method requires the following assumptions: (1) $\mathrm{SO}_{4}$ is not lost along the course of rivers by precipitation, and (2) $\mathrm{SO}_{4}$ concentrations reflect its continuous replenishment by hydrothermal activity. 


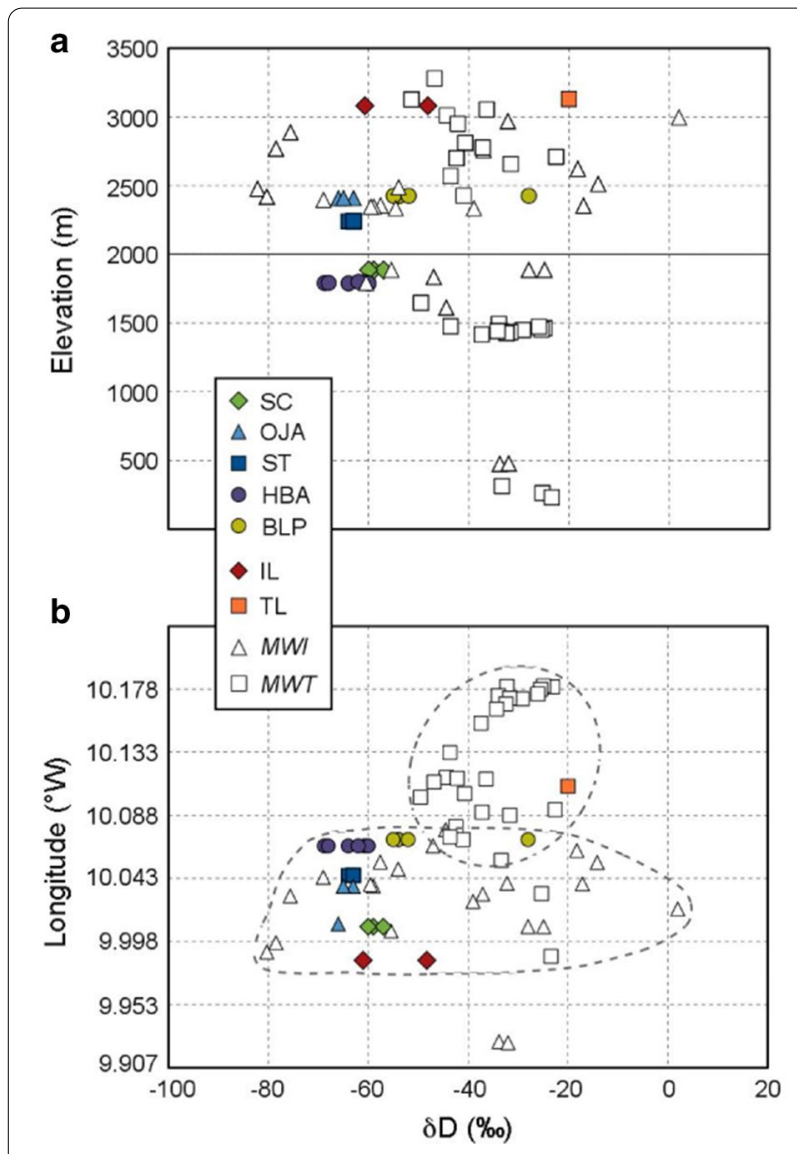

Fig. 6 Plots of $\delta D$ vs elevation (a) and longitude (b) for the thermal springs and Irazú-Turrialba lake waters compared with meteoric waters for Irazú (MWI) and Turrialba (MWT). In $\mathbf{b}$ the gray dotted fields illustrate the bulk of Irazú and Turrialba meteoric water samples

The former is a reasonable assumption considering that anhydrite is the major secondary product, but a mineral with reverse solubility, hence more soluble in colder river water. Moreover, gypsum, another possible $\mathrm{SO}_{4}$ sink from spring to river, is also under-saturated at the low temperatures of the rivers (Fig. 11).

Discharges of rivers were measured directly in the field by means of a flow probe. As flow rates from large rivers are difficult to estimate, the total relative error of the measured flow rates probably reaches $20 \%$. Values for $\mathrm{Q}$ and $\mathrm{SO}_{4}$ concentrations $(\mathrm{C})$ of rivers and thermal springs are presented in Table 6.

As mentioned before, San Cayetano spring discharges into the Río Caliente River, before converging with Río Sucio on the north flank of Irazú (Fig. 1b). Santa Teresita and Bajo Las Peñas springs are drained by Río Toro Amarillo, and Ojo de Agua discharges into Quebrada Ojo de Agua River that converges with Río Toro Amarillo, on the north flank of Turrialba (Fig. 1b). Río Sucio and Río Toro Amarillo are the major rivers on the north flank of Irazú and Turrialba, respectively (Fig. 1b). Hervideros de Buenos Aires springs are drained by Río Birris, a river on the south flank of the volcanoes (Fig. 1b).

The spring discharges (Qs) of the Santa Teresita and Bajo Las Peñas springs were calculated considering these two thermal springs together, as field logistics did not permit to measure single stream discharges (Table 6). We hence use a hypothetical Qs for all the thermal springs discharging into Río Toro Amarillo and subtract Qs of Ojo de Agua to obtain Qs of Santa Teresita. The highest and lowest concentrations of $\mathrm{SO}_{4}$ of these three thermal springs (Santa Teresita, Bajo Las Peñas and Ojo de Agua) are considered (the highest value of $1732 \mathrm{mg} / \mathrm{L}$ belongs to Santa Teresita, the lowest one of $263 \mathrm{mg} / \mathrm{L}$ to Bajo Las Peñas), thus estimating maximum and minimum Qs.

Unfortunately, it was impossible and too dangerous to directly measure Qr of Río Sucio and Río Toro Amarillo Rivers for being too deep and turbulent to wade through. The Qr of Río Sucio was re-calculated by referring to that of Río Caliente (that is more precise), which is actually one of its upstream tributaries. The Qr of Río Toro Amarillo is estimated to be of the same order of magnitude as Qr for Río Sucio.

Ojo de Agua ( $\mathrm{Qs}<1 \pm 0.2 \mathrm{~L} / \mathrm{s})$ and Hervideros de Buenos Aires (Qs $\sim 4 \pm 0.8 \mathrm{~L} / \mathrm{s}$ ) springs have the lowest discharge rates (Table 6). Consequently, Ojo de Agua provided a limited contribution to the total Qr of Río Toro Amarillo, compared to Santa Teresita and Bajo Las Peñas springs. Instead, San Cayetano has the highest Qs $(100 \pm 20 \mathrm{~L} / \mathrm{s})$. To verify Qs of the San Cayetano springs (an ASC spring), the only one with a high-Cl drainage (Río Caliente, Table 3), we applied the Cl-inventory method, in analogy with Eq. (2). The calculated Qs of San Cayetano results in $101 \pm 20 \mathrm{~L} / \mathrm{s}$, practically identical to the value obtained through the $\mathrm{SO}_{4}$-inventory method, justifying the above assumptions made regarding the conservative nature of $\mathrm{SO}_{4}$ downstream along the river. The high Qs confirms the earlier hypothesis of San Cayetano tapping a deeper and larger hydrothermal system (Taran and Kalacheva 2020). The total Qs of the Santa Teresita and Bajo Las Peñas springs is somewhere between $12 \pm 2.4$ and $82 \pm 16 \mathrm{~L} / \mathrm{s}$, considering the highest (Santa Teresita) and lowest (Bajo Las Peñas) $\mathrm{SO}_{4}$ content, respectively.

Summing the Qs of all the thermal springs (Qtot $=187 \pm 37 \mathrm{~L} / \mathrm{s}$ ) and multiplying it by the residence time (RT) of the water inside the hydrothermal system, it is possible to estimate the total volume of the geothermal aquifers (Taran and Kalacheva 2020):

$$
V=\mathrm{Q} \text { tot } * \mathrm{RT}
$$

where $V$ is the estimated volume of the aquifer $\left(\mathrm{m}^{3}\right.$ or L). 
오 د

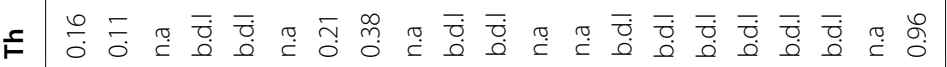
ฉ F

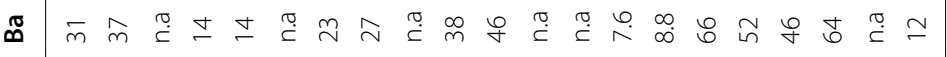

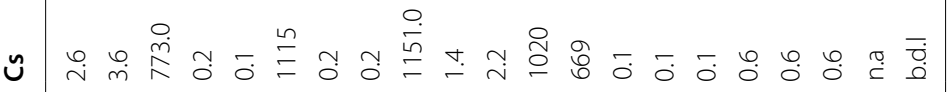

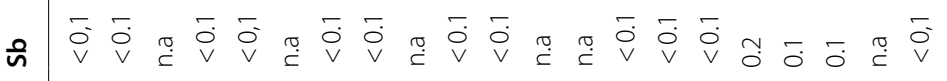

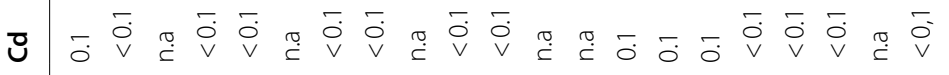

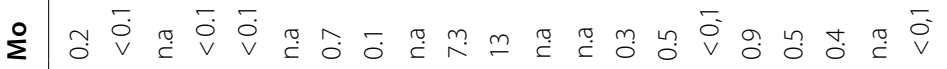

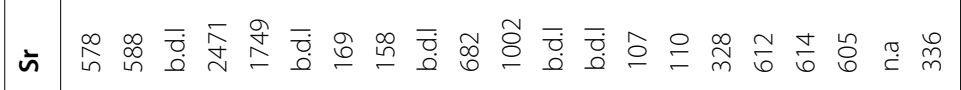

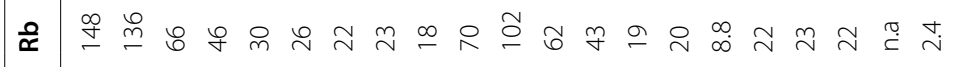

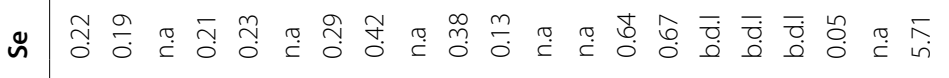

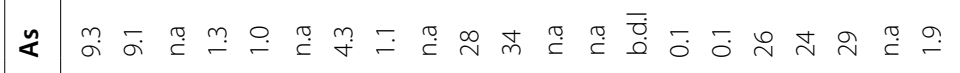

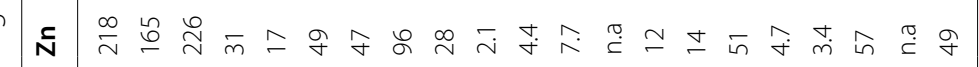

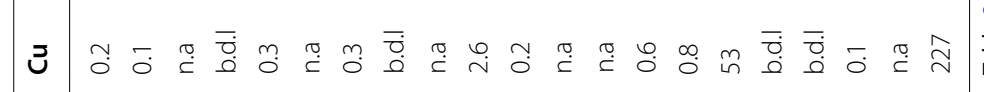

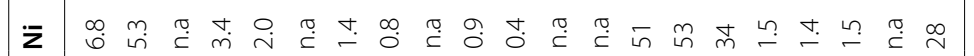

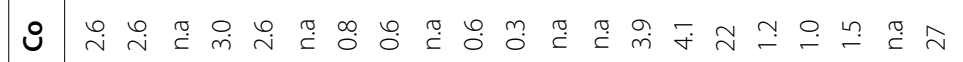

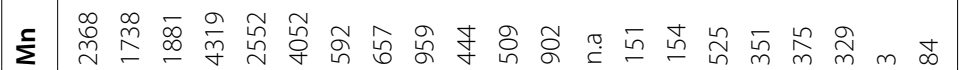

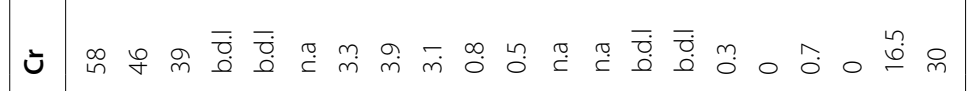

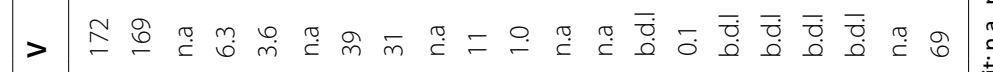

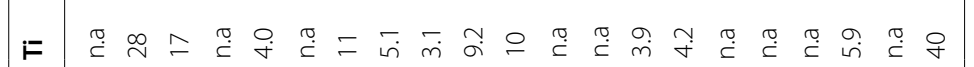

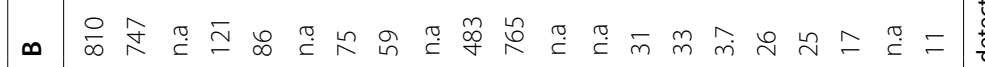

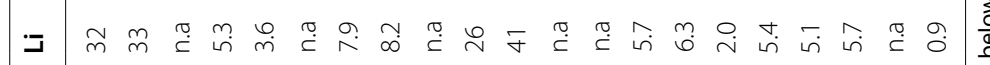

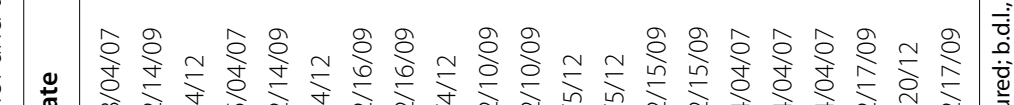
âd 先 


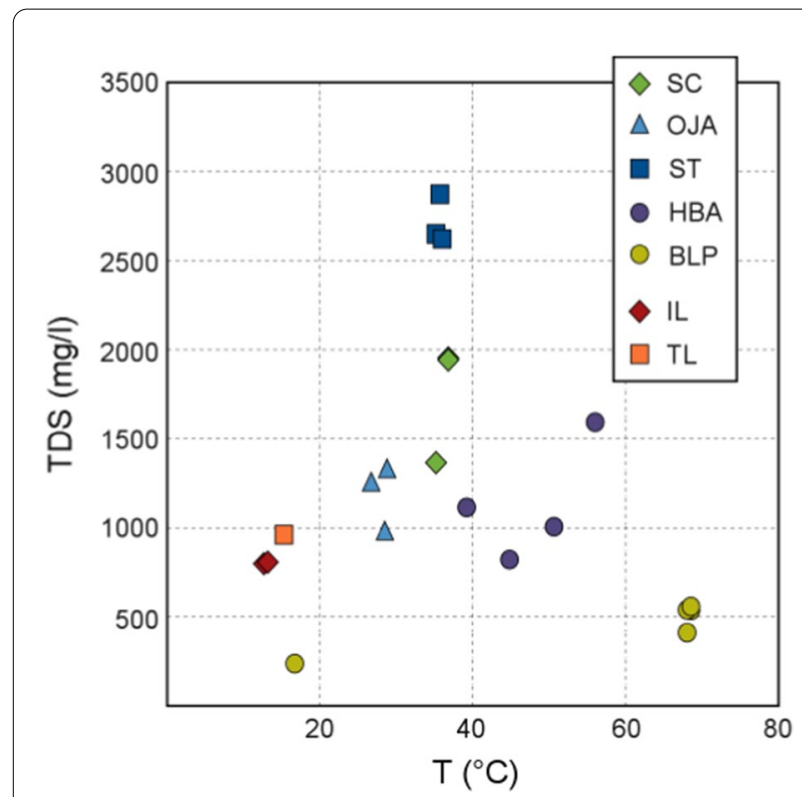

Fig. 7 Temperature vs Total Dissolved Solids (TDS) for the thermal spring waters (SC San cayetano, ST Santa Teresita, OJA Ojo de Agua, BLP Bajo Las Peñas, HBA Hervideros de Buenos Aires) and IrazúTurrialba lake waters (IL Irazú lake, TL Turrialba lake)

The RT given by Rowe et al. (1995) and Sanford et al. (1995) ranges between 3 to 17 years and 1 to 30 years, respectively, for Poás thermal spring waters (in Costa Rica), while Peiffer et al. (2015) estimated an RT of 3 to 13 years for El Chichón volcano-hydrothermal system (in Mexico). As recently discussed by Taran and Kalacheva (2020), high discharge hydrothermal systems are generally indicative of fast fluid flushing, hence resulting in shorter residence times. Assuming a residence time of 10 to 20 years for Irazú-Turrialba and a total Qs of thermal waters of $187 \pm 37 \mathrm{~L} / \mathrm{s}$ (i.e. a relatively high flux), the total volume of the various thermal aquifers feeding the springs in the study area is in the order of $\sim 5 \times 10^{7}-10^{8}$ $\mathrm{m}^{3}$ (or $\sim 5 \times 10^{10}-10^{11} \mathrm{~L}$ ). This aquifer volume is consistent with low porosity volcanic deposits of $5 \%$ (Peiffer et al. 2015), a feasible estimate for the highly altered deposits of the Irazú-Turrialba northern flank.

\section{Energy budget for thermal springs}

Once the spring output fluxes are calculated, an estimate of the total energy output by the thermal springs of Turrialba and Irazú can be obtained by multiplying the variation in liquid enthalpy for the deep fluid [i.e. for the geothermometric temperature of each spring, $H_{\mathrm{GT}}(\mathrm{kJ} /$ $\mathrm{kg})]$ cooled to spring outlet temperatures $\left[H_{\mathrm{sT}}(\mathrm{kJ} / \mathrm{kg})\right.$ ], with the spring output fluxes [Qs (L/s), Table 6] (Collard et al. 2014, 2020; and references therein). Unsurprisingly, the San Cayetano spring exhibits an energy
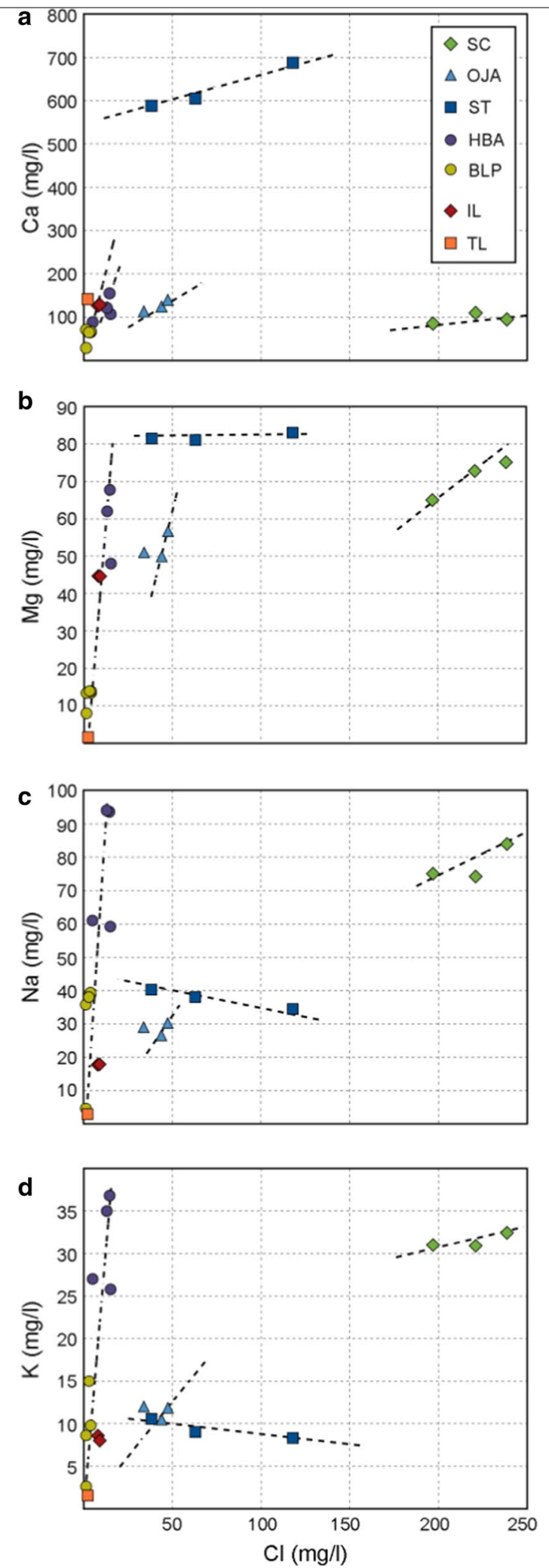

Fig. 8 Cation mixing plots for the thermal spring waters and IrazúTurrialba lake waters: a Cl vs Ca; b Cl vs Mg; c Cl vs Na; $\mathbf{d} \mathrm{Cl}$ vs $\mathrm{K}$. Dotted lines illustrate the possible trends corresponding to dilution with meteoric waters (except for Santa Teresita) 

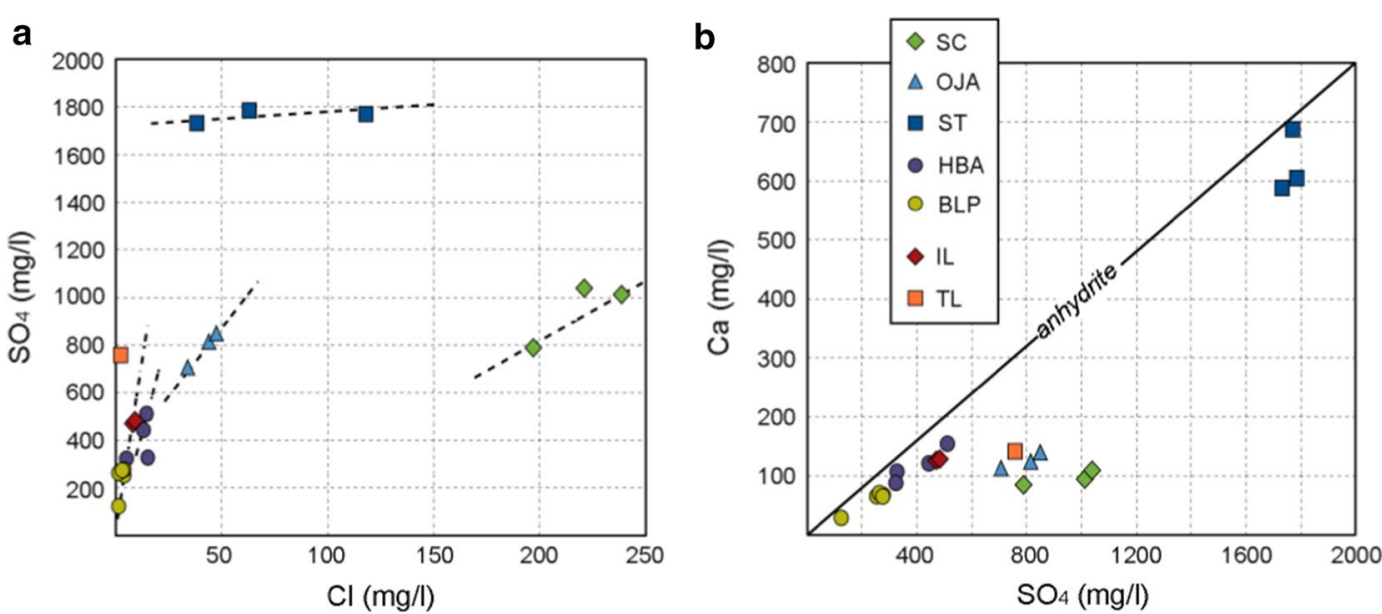

Fig. 9 Anion mixing plots for the thermal spring waters and Irazú-Turrialba lake waters. a Dotted lines illustrate the possible trends corresponding to dilution with meteoric waters (except for Santa Teresita). $\mathbf{b}$ Line represent the $\mathrm{SO}_{4} / \mathrm{Ca}$ ratio of anhydrite

a

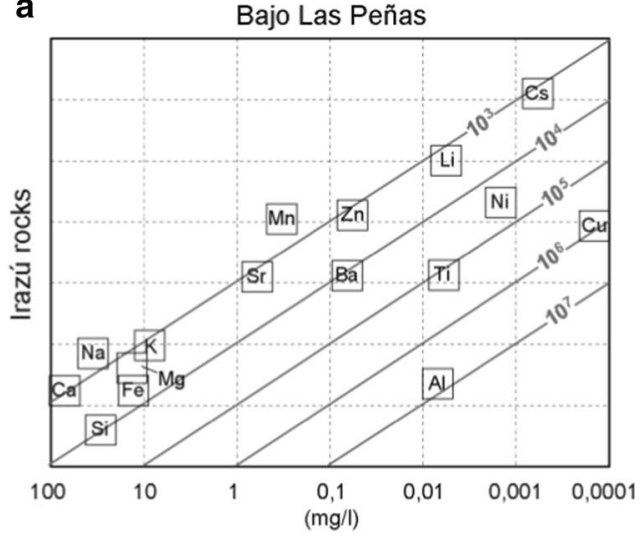

C

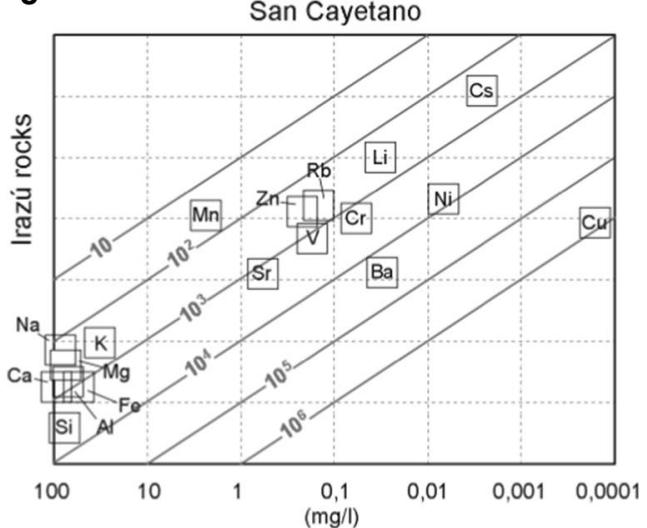

b

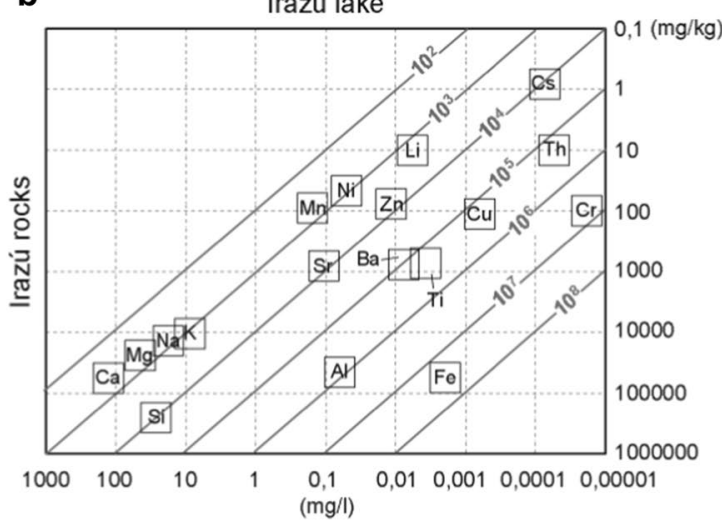

d

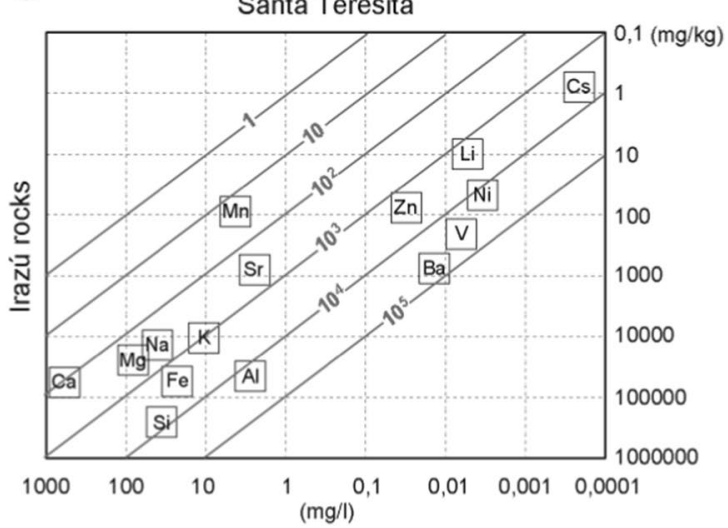

Fig. 10 Plots of element concentrations (in mg/L) in the main thermal springs (Bajo Las Peñas, San Cayetano and Santa Teresita) and Irazú lake vs average element concentrations in Irazú rocks (in $\mathrm{mg} / \mathrm{kg}$ ), which are fully comparable to those of Turrialba rocks. Chemical compositions of Irazú and Turrialba rocks are averaged from published data: Clark et al. (1998), Benjamin et al. (2007) for Irazú rocks (\# 30 samples); Reagan and Gill (1989) for Turrialba's rocks (\# 7 samples). Oblique lines indicate water-rock ratios ranging from 1 to $10^{8}$ 


\section{a}

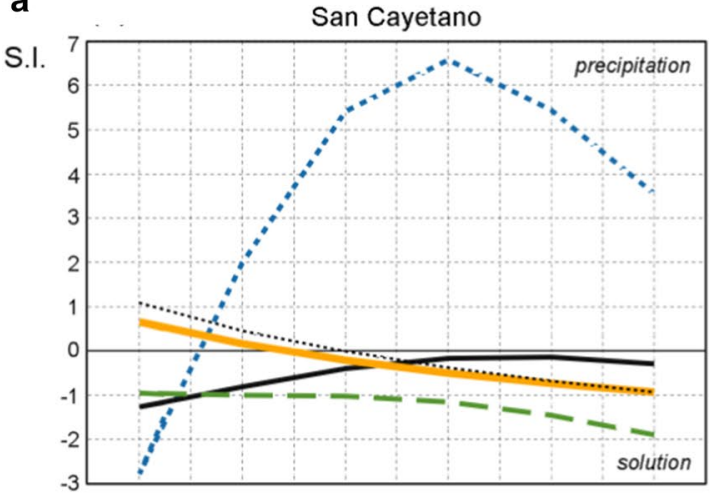

C

S.I.

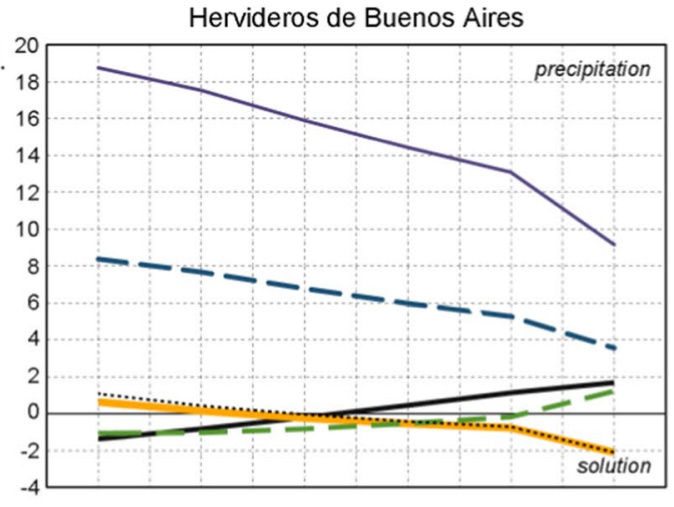

e

S.I.
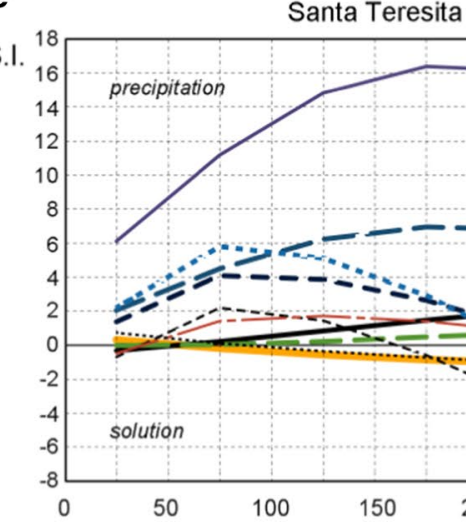

Santa Teresita

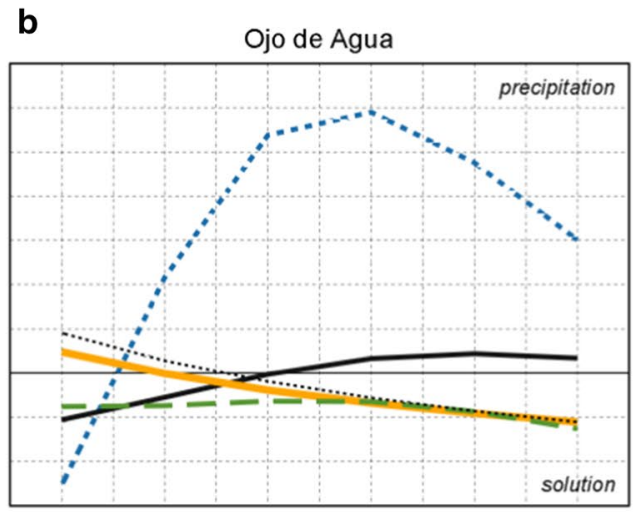

d
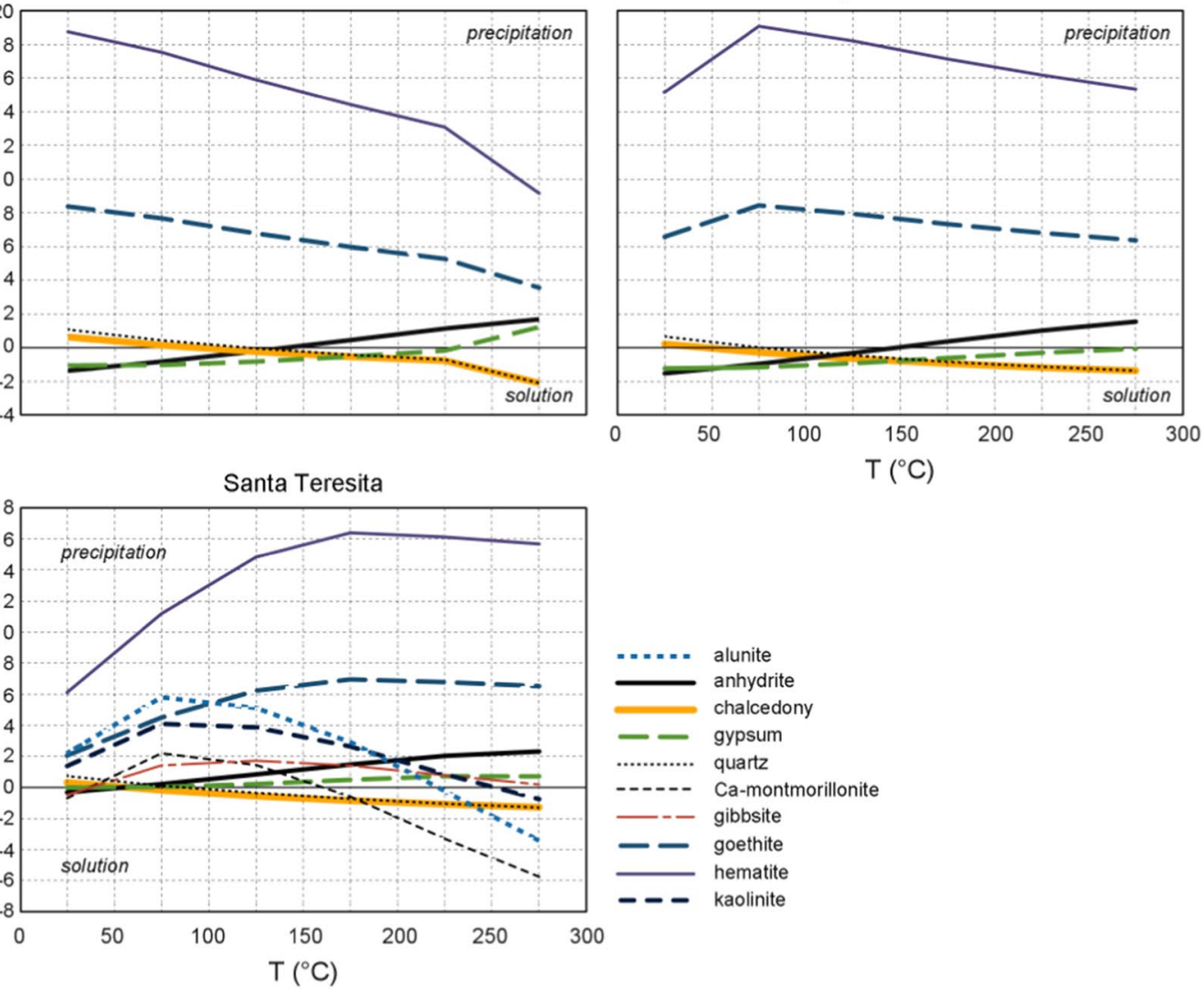

Fig. 11 Temperature vs Saturation Index (S.I.) for various minerals in the studied thermal springs, and corresponding fields of precipitation and solution related to the equilibrium line $(S . I=0)$. Anhydrite is used as a geothermometric indicator of different equilibrium temperature ranges for the thermal springs; for San Cayetano (a), Ojo de Agua (b), Hervideros de Buenos Aires (c), Bajo Las Peñas (d) and Santa Teresita (e). We use the tangency area between the anhydrite and equilibrium lines to estimate a temperature range

output of $83.9 \pm 16.8 \mathrm{MW}$, corresponding to $76.4 \%$ of the total energy output of nearly $110 \pm 22 \mathrm{MW}$ for the entire Irazú-Turrialba spring system (Table 6). Assuming a 50/50 split in the discharge of Bajo Las Peñas and Santa Teresita springs (i.e. 41/41 L/s), an energy output for both spring groups is estimated as $16.6 \pm 3.3$ and $7.6 \pm 1.5 \mathrm{MW}$
(15.1 and $6.9 \%$ of the total energy output), respectively. Ojo de Agua and Hervideros de Buenos Aries spring groups account for minor energy output contributions of $0.3 \pm 0.06$ and $1.4 \pm 0.3 \mathrm{MW}$ each (Table 6). Compared to other similar size volcano-hydrothermal systems with thermal spring discharges, a total energy output of 
Table $6 \mathrm{SO}_{4}$ concentrations and discharge $\left(\mathrm{QSO}_{4}\right)$ and water discharge (Q) of thermal springs and main rivers of Irazú and Turrialba

\begin{tabular}{|c|c|c|c|c|c|}
\hline Hot springs + rivers & $\begin{array}{l}\mathrm{SO}_{4} \\
\mathrm{mg} / \mathrm{L}\end{array}$ & $\begin{array}{c}\mathrm{QSO}_{4} \\
\mathrm{mg} / \mathrm{s}\end{array}$ & $\begin{array}{l}Q \\
L / s\end{array}$ & $\begin{array}{l}\mathrm{Hs} \\
\mathrm{kJ} / \mathrm{kg}\end{array}$ & $\begin{array}{l}\text { Es } \\
\text { MW }\end{array}$ \\
\hline Río Sucio & 445 & 101,420 & 228 & - & - \\
\hline Río Toro Amarillo & 95 & 21,712 & 228 & - & - \\
\hline $\begin{array}{l}\text { Quebrada Ojo de } \\
\text { Agua }\end{array}$ & 529 & 529 & 1 & - & - \\
\hline Río Birris & 13 & 1300 & 100 & - & - \\
\hline Río Caliente & 922 & 101,420 & 110 & - & - \\
\hline SC & 1012 & 101,420 & 100 & 839.3 & 83.9 \\
\hline $\mathrm{BLP}+\mathrm{ST}$ & 263 & 21,541 & 82 & $404.4+184.1$ & $16.6+7.6$ \\
\hline OJA & 815 & 529 & 0.65 & 467.5 & 0.3 \\
\hline HBA & 327 & 1300 & 3.98 & 358.9 & 1.4 \\
\hline Total & - & - & - & - & 109.8 \\
\hline
\end{tabular}

- Not applicable. Abbreviations as in Table 2

$110 \pm 22$ MW for Irazú-Turrialba is in the same order of magnitude as for Poás and El Chichón volcanoes (Rowe et al. 1992; Taran and Peiffer 2009), nearly double than for Copahue volcano (Varekamp et al. 2001), an order of magnitude higher than for Tacaná volcano (Collard et al. 2014, 2020), but an order of magnitude lower than for the extremely high-energy output of Domuyo volcano (Chiodini et al. 2014).

\section{Water mass budget for plume degassing}

The transition from hydrothermal to magmatic unrest (Vaselli et al. 2009; Rizzo et al. 2017) at Turrialba, with the occurrence of phreatic eruptions since 2010, significantly changed the degassing regime with a net increase of vapor loss through plume degassing (Campion et al. 2012; Conde et al. 2014; Moussalam et al. 2014; de Moor et al. 2016). To estimate this extra vapor loss, we used remotely sensed $\mathrm{SO}_{2}$ flux measurements and contemporaneous fumarole sampling analyses $\left(\mathrm{H}_{2} \mathrm{O} / \mathrm{SO}_{2}\right.$ ratio) carried out by others (Vaselli et al. 2009; Martini et al. 2010; Campion et al. 2012; Conde et al. 2014; Moussalam et al. 2014). Nevertheless, the estimated error of the $\mathrm{SO}_{2}$ flux measurements can be as high as $40 \%$ on average (Campion et al. 2012).

High-temperature fumaroles linked to the Southwest crater of Turrialba were detected between September 2007 and May 2008 (i.e. pre-phreatic phase; Vaselli et al. 2009); they have temperatures ranging from 185 to $282^{\circ} \mathrm{C}$, and $\mathrm{H}_{2} \mathrm{O} / \mathrm{SO}_{2}$ mass ratios ranging from 4 to 9 . The increase in $\mathrm{SO}_{2}$ concentration (up to $>300 \mathrm{mmol} / \mathrm{mol}$ ) is reflected in a decrease in the $\mathrm{H}_{2} \mathrm{O} / \mathrm{SO}_{2}$ ratio. Moussalam et al. (2014) measured $\mathrm{H}_{2} \mathrm{O} / \mathrm{SO}_{2}$ ratios directly in the plume by FTIR in March 2013 (i.e. syn-phreatic phase), and obtained a mass ratio of 17 .

Based on the $\mathrm{SO}_{2}$ flux variations and $\mathrm{H}_{2} \mathrm{O} / \mathrm{SO}_{2}$ ratio, we calculate how the vapor flux from plume degassing has varied during the period before and after the first phreatic eruption of 5 January 2010, when a significant increase of $\mathrm{SO}_{2}$ flux was detected, with the onset of jetlike plume degassing (Campion et al. 2012). $\mathrm{SO}_{2}$ flux rates increased from $6.3 \pm 6.3 \mathrm{~kg} / \mathrm{s}$ at the end of 2009 , and up to $50 \pm 20 \mathrm{~kg} / \mathrm{s}$ immediately after the 2010 eruption. Afterwards, $\mathrm{SO}_{2}$ flux rates detected during 2010-2011 have changed from $20 \pm 8$ to $50 \pm 20 \mathrm{~kg} / \mathrm{s}$ (Campion et al. 2012).

The $\mathrm{H}_{2} \mathrm{O}$ flux $\left(\mathrm{QH}_{2} \mathrm{O}, \mathrm{L} / \mathrm{s}\right)$ is calculated by:

$$
\mathrm{QH}_{2} \mathrm{O}=X * \mathrm{QSO}_{2}
$$

where $\mathrm{QSO}_{2}$ is the $\mathrm{SO}_{2}$ flux $(\mathrm{kg} / \mathrm{s})$ from the Turrialba plume [from Campion et al. (2012)] and $X$ is the adopted value of $\mathrm{H}_{2} \mathrm{O} / \mathrm{SO}_{2}$ mass ratio for the pre- [4 to 9; Vaselli et al. (2009)], and syn-phreatic phase [17; Moussalam et al. (2014)], as discussed before.

Accordingly, during the period July 2009-February 2011, the plume vapor flux increased from a background pre-eruption value of $62 \pm 50 \mathrm{~L} / \mathrm{s}$ up to a maximum of $1000 \pm 400 \mathrm{~L} / \mathrm{s}$ after the 2010 phreatic eruption. After that, the $\mathrm{H}_{2} \mathrm{O}$ flux has steadily decreased reaching values of $300 \pm 120 \mathrm{~L} / \mathrm{s}$, which can be considered the minimum $\mathrm{H}_{2} \mathrm{O}$ flux during the syn-phreatic period. Based on the maximum $\mathrm{SO}_{2}$ fluxes reported by Conde et al. (2014), for time intervals too long to enable a trustful comparison, and applying Eq. (4) with the same criteria for $X$, a similar trend is observed with pre-phreatic $\mathrm{H}_{2} \mathrm{O}$ fluxes of $149 \pm 91 \mathrm{~L} / \mathrm{s}$, and syn-phreatic $\mathrm{H}_{2} \mathrm{O}$ fluxes of $453 \pm 223$ $\mathrm{L} / \mathrm{s}$. The extra-discharge (Q-extra) over background due to vapor loss from Turrialba plume degassing can be calculated subtracting the background pre-eruption $\mathrm{H}_{2} \mathrm{O}$ flux $(62 \mathrm{~L} / \mathrm{s})$ from the average $\mathrm{H}_{2} \mathrm{O}$ flux of the synphreatic phase $(580 \mathrm{~L} / \mathrm{s})$. The average value of $\mathrm{Q}_{\mathrm{H} 2 \mathrm{O}}$-extra is $518 \mathrm{~L} / \mathrm{s}$. The 2005 and 2007 fumaroles (4 samples) reported by Vaselli et al. (2009) showed evidence of an $\mathrm{AW}$ contribution in fumarolic vapor of maximum $~ 50 \%$, corroborated by the single $\delta \mathrm{D}-\delta^{18} \mathrm{O}$ data of fumarolic steam in this study. Hence, a minimum estimated vapor flux of $259 \mathrm{~L} / \mathrm{s}$ originating from the Turrialba fumaroles is postulated, which is still an order of magnitude higher than the pre-eruptive vapor flux from fumaroles with a purely meteoric origin (1998-2004 samples by Vaselli et al. 2009). In conclusion, since January 2010 Turrialba 
has increased its output of vapor, which originates from the underlying hydrothermal system, through plume degassing by $259-518 \mathrm{~L} / \mathrm{s}$ over the probably more constant background water loss from thermal springs of $187 \pm 37 \mathrm{~L} / \mathrm{s}$. The increased degassing at Turrialba confirms the drying of the underlying hydrothermal systems, hypothesized by Moussalam et al. (2014), but, based on our findings, probably taps its waters from deeper than previously thought.

\section{Conceptual model}

A conceptual model for the magmatic-hydrothermal system of Irazú-Turrialba is presented based on the geographical distribution and geochemical characterization of thermal springs, crater lakes, rivers, and fumaroles (Fig. 12). The heterogeneous nature in chemistry of the Irazú-Turrialba thermal manifestations suggests that the magmatic-hydrothermal system is composed of smaller scale magmatic-hydrothermal sub-systems (MHS), each feeding "steam heated" $\mathrm{SO}_{4}$-rich, $\mathrm{Cl}$-poor thermal springs and crater lakes, with an accumulated volume of $\sim 10^{8} \mathrm{~m}^{3}$ estimated from a total discharge of thermal springs of $187 \pm 37 \mathrm{~L} / \mathrm{s}$. Our hydrogeochemical model considers a prevailing NE-to-SW direction of rains and winds from the Caribbean, based on the observed isotopic compositions $\left(\delta \mathrm{D}\right.$ and $\left.\delta^{18} \mathrm{O}\right)$ of $\mathrm{MW}$ for Irazú and Turrialba volcanoes. As demonstrated by the isotopic composition, meteoric waters of Turrialba are isotopically heavier than those of Irazú, which is located downwind in Turrialba's "rain shadow". The thermal springs in between the two volcanoes are also located in the "rain shadow", hence showing similar isotopic compositions as the Irazú MW (Table 2). This also counts for Bajo Las Peñas springs $\left(\sim-8 \%\right.$ o $\left.\delta \mathrm{D}, \sim-50 \% \delta^{18} \mathrm{O}\right)$, despite being located near Turrialba.

Bajo Las Peñas springs are located just below the eastern border of a large collapse structure. The collapse fault is assumed to tap these springs directly from depth, to explain the higher temperatures compared to the other spring groups (Table 2, Fig. 12). Similar chemical properties for the MHS that feeds the Hervideros de Buenos Aires are observed. Nevertheless, as Hervideros de Buenos Aires is located on the south flank of Irazú-Turrialba, it is related to an independent MHS (not shown in Fig. 12).

Santa Teresita, Ojo de Agua and San Cayetano springs, on the north flank of Irazú-Turrialba, likely have an independent MHS (Fig. 12). This architecture is supported by different geothermometric temperatures $\left(\sim 200-230{ }^{\circ} \mathrm{C}\right.$ at San Cayetano, $\sim 110-140{ }^{\circ} \mathrm{C}$ at Ojo de
Agua and $\sim 50-80{ }^{\circ} \mathrm{C}$ at Santa Teresita). Santa Teresita springs are less affected by $\mathrm{H}_{2} \mathrm{~S}$-oxidation processes, and their high $\mathrm{Ca}$ and $\mathrm{SO}_{4}$ contents merely originate from mixing with an anhydrite-leaching MW. The MHS feeding the San Cayetano springs is the major hydrothermal sub-system of Irazú-Turrialba, having the highest thermal water and energy output rates $(\sim 100 \pm 20 \mathrm{~L} / \mathrm{s}$ and $83.9 \pm 16.8 \mathrm{MW}$, respectively). Nevertheless, the possibility that the San Cayetano MHS feeds the Irazú nearsummit fumarolic field from below is unlikely for being located $1100 \mathrm{~m}$ below the fumaroles and crater lake. Thus, the near-summit fumaroles of the Irazú north flank are thought to be fed by gases and vapor from an independent near-summit MHS, probably also affecting the $\mathrm{SO}_{4}$-enriched Irazú crater lake, at the same elevation. As suggested by the stable isotopic compositions of the currently low-activity crater lake, the summit of Irazú provides water to the aquifers of the thermal springs (Fig. 5), whereas the spring water chemistry will be created in small scale, localized MHS, due to different hydrothermal degassing regimes.

Prior to the recent magmatic activity, Turrialba volcano had its own MHS below the summit area feeding the ephemeral crater lakes within the active Southwest and Central craters. Since January 2010, after the first phreatic eruption, jet-like plume degassing has released above background amounts of $\mathrm{SO}_{2}$ and $\mathrm{H}_{2} \mathrm{O}$ (Martini et al. 2010; Conde et al. 2014; Moussalam et al. 2014; de Moor et al. 2016). Before the 5 January 2010 eruption, the $\mathrm{H}_{2} \mathrm{O}$ plume flux was minimum $(62 \pm 50 \mathrm{~L} / \mathrm{s})$ accounting for a yearly loss of $\sim 2 \%$ of the estimated volume of the Irazú-Turrialba hydrothermal aquifers. The $\mathrm{H}_{2} \mathrm{O}$ flux significantly increased immediately after the 2010 eruption up to $580 \mathrm{~L} / \mathrm{s}$. This corresponds to an extra water loss of $\sim 518 \mathrm{~L} / \mathrm{s}$, accounting for $\sim 16 \%$ of water loss of the estimated volume of the hydrothermal aquifers. Although part of this extra vapor loss could originate directly from the magma as AW ( 50\% maximum), we suggest that this strong increase in water loss by plume degassing has significantly affected the Irazú-Turrialba hydrodynamics, eventually resulting in the disappearance of Irazú crater lake, steadily dropping its lake level since 2007, coinciding with increased unrest at Turrialba. Within this working hypothesis, the Irazú crater lake should not recover, unless plume degassing at Turrialba reaches a new steady-state condition. Despite hurricane Otto striking Costa Rica in November 2016, the crater lake has reappeared consistently only during the 2017 rainy season, when Turrialba's unrest waned with respect to previous years. 


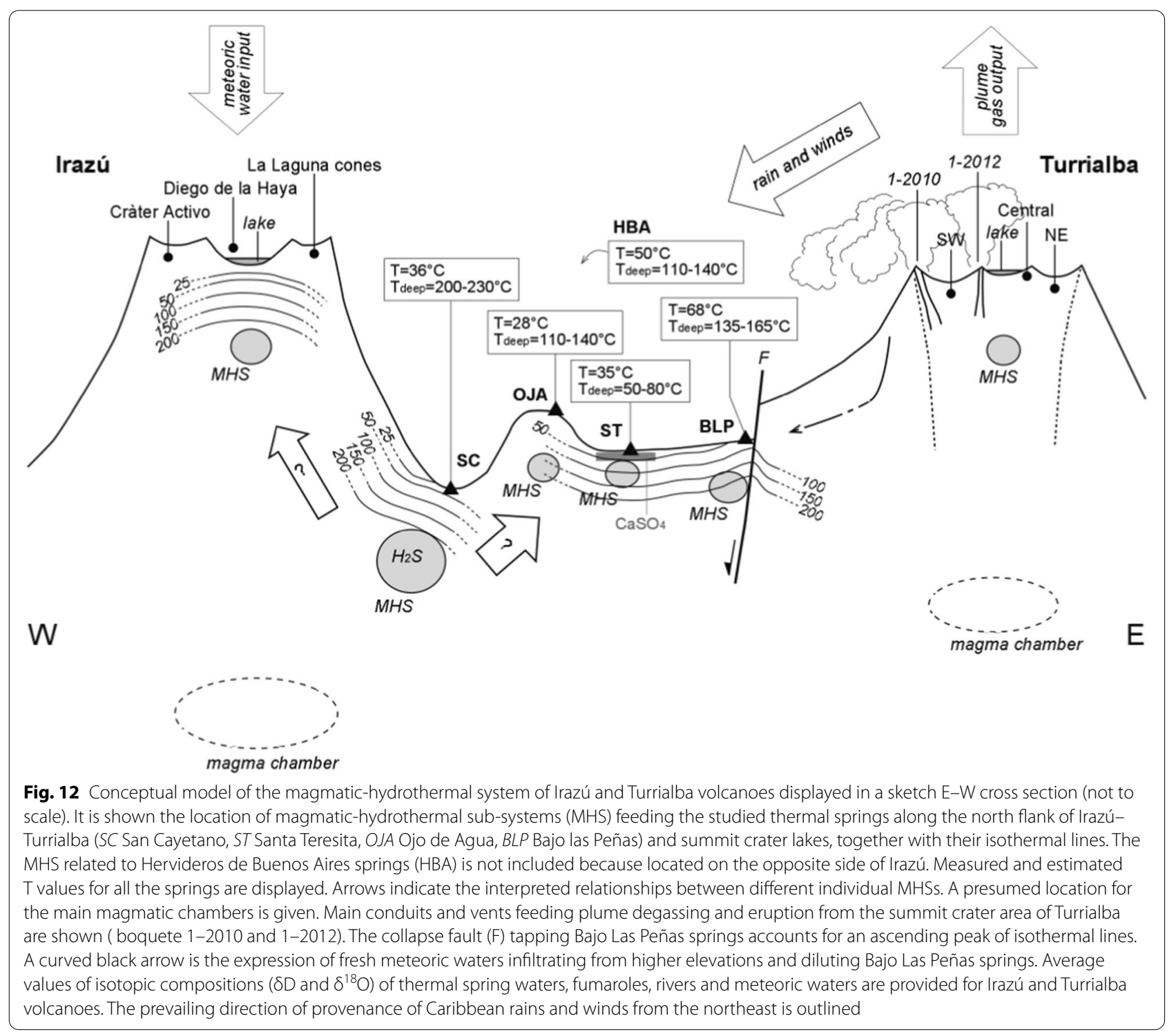

\section{Implications for hazard assessment and future monitoring at Irazú-Turrialba}

It is well known that flank failure or collapses in volcanic areas may be favored by hydrothermal alteration. Physical-chemical weathering of the hydrothermal, acid sulfate-clay alteration of volcanic rocks leads to a pervasive fracturing of the rock mass, and is transient to long-term variations of rock strength properties and pore-fluid pressure (Delmelle et al. 2015, and references therein). Within their typical lifetime (i.e. decades to centuries), hydrothermal systems cause rock dissolution and removal after prolonged seepage of acidic fluids. A major contribution of our hydrogeochemical study is to identify the main hydrothermally altered, collapse-prone areas along the flanks of Irazú-Turrialba.

The hydrothermally altered areas associated with thermal springs, are generally located in correspondence to older collapse structures (Fig. 1), proving that hydrothermal activity is structurally controlled. As such, the northern and northwestern flanks of Irazú are the weakest sectors of the volcano, with Río Sucio discharging San Cayetano thermal springs and the near-summit fumarolic field. The Río Sucio-San 
Cayetano system has a hot water discharge of $100 \pm 20$ $\mathrm{L} / \mathrm{s}$ (Table 6), corresponding to $53 \%$ of the total water output. Based on the $\mathrm{SO}_{4}$ discharge and corresponding $\mathrm{SO}_{4} / \mathrm{RFE}$ ratios (where RFE stands for rock-forming elements), we estimate a rock removal rate by chemical weathering of $\sim 2430 \mathrm{~m}^{3} /$ year for the Río Sucio-San Cayetano system (Table 7). This represents a substantial part $(\sim 80 \%)$ of the rock removal rate of $\sim 3040 \mathrm{~m}^{3} /$ year for the whole Irazú-Turrialba thermal springs. These removal rates are comparable to estimates for the nearby Poás volcano $\left(1650-4300 \mathrm{~m}^{3} /\right.$ year; Rowe et al. 1995), where more acidic waters leach the yet smaller volcanic edifice. The rock loss by chemical leaching and hydrothermal alteration is clearly shown by Río Sucio discharging brown-orange waters arguably formed when dissolved solutes become particulate loads by $\mathrm{Fe}$ oxidation along the flow path of the river.

A consequence of hydrothermal argillic alteration may be the development of low-permeability layers along the flanks of the volcano, sealing the hydrothermal fluids and causing the increase of pore-fluid pressure within the volcanic core (Moore et al. 2004, 2008; Delmelle et al. 2015; Mick et al. 2021). Pressure build-up beneath seals can culminate into "Type 1" seal-breaching phreatic eruptions, as recently classified by Stix and de Moor (2018), also based on the current Turrialba phreatic eruptive stage (Mick et al. 2021). Moreover, hydrothermal pressurization can contribute to slope failure, followed by a sudden decompression and flash boiling in the underlying thermal aquifer that can cause phreatic or hydrothermal eruptions.

As Turrialba, the currently quiescent Irazú could reawaken to manifest a similar, potentially hazardous behavior, possibly with eruptive activity, increased fumarolic degassing along the north flank, phreatic eruptions, or flank failure events. Irazú's summit area has been affected by an accelerating deformation since 2014. Within the views of our deterministic hazard assessment, we stress the need to better time-frame the physical-chemical processes that lead to flank instability and collapse, particularly if we deem that they may be hard to forecast for not necessarily being related to a magma on the move (Rouwet et al. 2014b).

\section{Conclusion}

This first hydrogeochemical survey of Irazú-Turrialba provided the following results in terms of volcanohazard monitoring. A conceptual model for the IrazúTurrialba magmatic-hydrothermal system shows that the spring clusters located along the north flank are currently the main sites of magmatic-hydrothermal activity besides the recent summit eruptive activity of Turrialba.

A water budget for Turrialba plume degassing during the current eruptive unrest phase indicates a substantial increase of fumarolic vapor flux, corresponding to a water loss from the Irazú-Turrialba hydrothermal aquifer, which could explain the disappearance of Irazú crater lake in the spring of 2010, after years of steady lake-level drop. The hydrothermal sub-systems each reflect their particular generic processes in terms of chemistry, although with a common steam-heated, $\mathrm{SO}_{4}$-rich nature. In terms of water mass they are part of many thermal aquifers between Irazú and Turrialba, fed by meteoric recharge and a total discharge rate of $187 \pm 37 \mathrm{~L} / \mathrm{s}$, accounting for an energy output of nearly $110 \pm 22$ MW.

Based on the chemical compositions and water output rates of thermal springs, the San Cayetano-Río Sucio system is the most efficient rock remover by chemical leaching and physical weathering, outlining the near-summit fumarolic field along the north and northwest flank of Irazú as the most probable source area for structural collapse of the volcano and indirect hazards (e.g. debris avalanches, phreatic eruptions), despite the current volcanic quiescence. A more frequent geochemical and geodetical monitoring of the San Cayetano-Río Sucio system, and the near-summit fumarolic field of Irazú is expected to improve volcano-hazard evaluations. In fact, the northwest summit area deformed and fractured at increasing rates since November 2014, and temporarily accelerated in the summer of 2020 (Muller et al. 2020). This confirms the potentially high impact of slow processes, such as chemical and physical rock weathering, on volcanic edifice stability. 


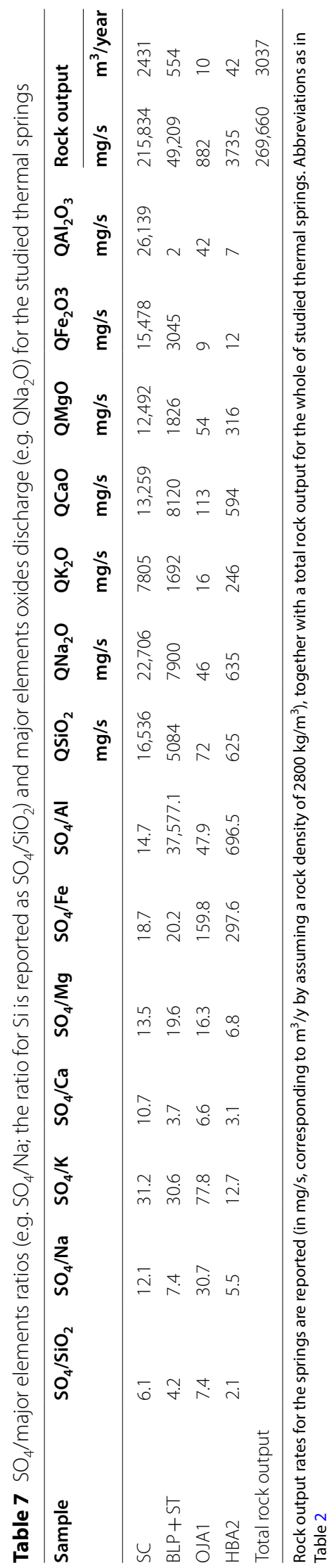




\section{Abbreviations}

m a.s.l.: Meters above sea level; MW: Meteoric water; AW: Andesitic water; AMI: Meteoric water Irazú; AMT: Meteoric water Turrialba; TDS: Total dissolved solids; GMWL: Global meteoric water line; IMWL: Irazú meteoric water line; TMWL: Turrialba meteoric water line; SI: Saturation index; IAP: Ion activity product; MHS: Magmatic-hydrothermal sub-systems; RFE: Rock forming elements; SC: San Cayetano; ST: Santa Teresita; OJA: Ojo de Agua; HBA: Hervideros de Buenos Aires; BLP: Bajo Las Peñas; IL: Irazú crater lake; IF: Irazú fumarole; TL: Turrialba crater lake; TF: Turrialba fumarole.

\section{Acknowledgements}

Funding for DR came from UCR for the period 2007-2012, INGV-Dipartimento Vulcani (FREAPROB) for the period 2015-2016. This study was closed during the Pianeta Dinamico-TaskV2 internal INGV project, dedicated to phreatic eruptions. We thank Aldo Sollami, Igor Olivieri (INGV-Palermo) for isotopic analysis of samples; Lorenzo Brusca and Sergio Bellomo (INGV-Palermo) for some trace analyses; a ranger of the Parques Nacionales Volcán Turrialba y Volcán Irazú; Y. Alpízar helped in the Hillside or ShadowRelieve of Fig. 1. We are grateful to two anonymous reviewers for their constructive comments that increased the quality of our study. T. Fischer is thanked for efficient editorial handling.

\section{Authors' contributions}

DR: main author, field work, analyses, elaboration of data, writing of the MS. RMA: field logistics, field work, elaboration of data, discussion on content. CR: field logistics, field work, elaboration of data, discussion on content. GG: field logistics, field work, elaboration of data, discussion on content. EB: MSC student, analyses, elaboration of data, figure editing, writing of the original draft. GP: analytical support, discussion on content, editing of figures and text. SI: analytical support, discussion on content, editing of Tables. BC: analytical support, discussion on content. FL: discussion on content, hazard assessment, writing of the MS. CAT: discussion on content, hazard assessment, editing of the MS. All authors read and approved the final manuscript.

\section{Funding}

Funding was made available for DR by Universidad de Costa Rica.

\section{Availability of data and materials}

All data in this study are presented as Tables.

\section{Declarations}

Ethics approval and consent to participate

Not applicable.

\section{Competing interests}

The authors declare to not have competing interest with other research groups.

\section{Author details}

${ }^{1}$ Istituto Nazionale Di Geofisica E Vulcanologia, Sezione Di Bologna, Bologna, Italy. ${ }^{2}$ Volcanes Sin Fronteras, San José, Costa Rica. ${ }^{3}$ Servicio Geológico Ambiental de Costa Rica (SeGeoAm), San José, Costa Rica. ${ }^{4}$ Volcanes Sin Fronteras, San José, Costa Rica. ${ }^{5}$ Università Degli Studi Aldo Moro, Bari, Italy. ${ }^{6}$ BIGEA, Alma Mater Studiorum, Università Di Bologna, Bologna, Italy. ${ }^{7}$ IVAR, Universidade Dos Açores, Ponta Delgada, São Miguel, Azores, Portugal. ${ }^{8}$ Istituto Nazionale Di Geofisica E Vulcanologia, Sezione Di Palermo, Palermo, Italy.

Received: 30 December 2020 Accepted: 24 June 2021

Published online: 12 July 2021

\section{References}

Alpízar Y, Mora-Amador R, González G, Ramírez CJ, Moral MM, Taylor W (2014) Actividad de los volcanes de Costa Rica durante el periodo 2012-2013/ Activity of the Costa Rica volcanoes during 2012-2013. Rev Geol Amér Central 51:145-158. https://doi.org/10.15517/rgac.v51i1.16910.a Alvarado GE (2005) Costa Rica: land of volcanoes. EUNED, San José
Alvarado GE, Schmincke HU (1994) Stratigraphic and sedimentological aspects of the rain triggered lahars of the 1963-1965 Irazú eruption, Costa Rica. Zentralblat Für Geologieuna Paläontologie 1(1-2):513-550

Alvarado GE, Schmincke HU (2013) The 1723 A.D. violent strombolian and phreatomagmatic eruption at Irazú volcano, Costa Rica (La erupción estromboliana violenta y freatomagmática de 1723 en el volcán Irazú, Costa Rica). Rev Geol Am Central 48:41-61

Alvarado GE, Carr MJ, Turrin, Brent D, Swisher CC, Schmincke HU, Hudnut KW (2006) Recent volcanic history of Irazú volcano, Costa Rica: alternation and mixing of two magma batches, and pervasive mixing. In: Rose WI, Bluth GJS, Carr MJ, Ewert J, Patino LC, Vallance J (eds) Volcanic hazards in Central America. Geol Soc Am Special Pap 412:259-276. https://doi.org/ 10.1130/2006.2412(14)

Alvarado GE, Mora MM, Ulloa A (2013) La caida de "ceniza" provenience del volcano Irazú (Costa Rica) el 8 de diciembre de 1994. Rev Geol Am Central 48:159-168

Alvarado GE, Mele D, Dellino P, de Moor JM, Avard G (2016) Are the ashes from the latest eruptions (2010-2016) at Turrialba volcano (Costa Rica) related to phreatic or phreatomagmatic events? J Volcanol Geotherm Res 327:407-415. https://doi.org/10.1016/j.jvolgeores.2016.09.003

Benjamin ER, Plank T, Wade JA, Kelley KA, Hauri EH, Alvarado GE (2007) High water contents in basaltic magmas from Irazú Volcano, Costa Rica. J Volcanol Geotherm Res 168:68-92

Bruijnzeel LA, Mulligan M, Scatena FN (2011) Hydrometeorology of tropical montane cloud forests: emerging patterns. Hydrol Process 25:465-498

Campion R, Martínez-Cruz M, Lecoq T, Caudron C, Pacheco J, Pinardi G, Hemans C, Carn S, Bernard A (2012) Space- and ground-based measurements of sulphur dioxide emissions from Turrialba Volcano (Costa Rica). Bull Volcanol. https://doi.org/10.1007/s00445-012-0631-z

Chiodini G, Liccioli C, Vaselli O, Calabrese S, Tassi F, Caliro S, Caselli A, Agusto M, D'Alessandro W (2014) The Domuyo volcanic system: an enormous geothermal resource in Argentine Patagonia. J Volcanol Geotherm Res 274:71-77

Clark SK, Reagan MK, Plank T (1998) Trace element and U-series systematics for 1963-1965 tephras from Irazú Volcano, Costa Rica: implications for magma generation processes and transit times. Geochim Cosmochim Acta 62(15):2689-2699

Clark SK, Reagan MK, Trimble DA (2006) Tephra deposits for the past 2600 years from Irazú volcano, Costa Rica. In: Rose WI, Bluth GJS, Carr MJ, Ewert J, Patino LC, Vallance J (eds) Volcanic hazards in Central America. Geol Soc Am Special Pap 412:225-234. https://doi.org/10.1130/2006.2412(12).

Collard N, Taran YA, Peiffer L, Campion R, Jácome-Paz MP (2014) Solute fluxes and geothermal potential of Tacaná volcano-hydrothermal system Mexico-Guatemala. J Volcanol Geotherm Res. https://doi.org/10.1016/j. jvolgeores.2014.10.012

Collard N, Peiffer L, Taran Y (2020) Heat and fluid flow dynmics of a stratovolcano: the Tacaná Volcanic Complex. Mexico-Guatemala J Volcanol Geotherm Res. https://doi.org/10.1016/j.jvolgeores.2020.106916

Conde V, Bredemeyer S, Duarte E, Pacheco JF, Miranda S, Galle B, Hansteen TH (2014) $\mathrm{SO}_{2}$ degassing from Turrialba Volcano linked to seismic signatures during the period 2008-2012. Int J Earth Sci 103:1983-1998. https://doi. org/10.1007/s00531-013-0958-5

de Moor JM, Aiuppa A, Avard G, Wehrmann H, Dunbar N, Muller C, Tamburello G, Giudice G, Liuzzo M, Moretti R, Conde V, Galle B (2016) Turmoil at Turrialba volcanic (Costa Rica): degassing and eruptive processes inferred from high-frequency gas monitoring. J Geophys Res Solid Earth. https:// doi.org/10.1002/2016JB013150

Delmelle P, Bernard A (2000) Downstream composition changes of acidic volcanic waters discharged into the Banyupahit stream, ljen caldera, Indonesia. J Volcanol Geotherm Res 97:55-75

Delmelle P, Henley RW, Opfergelt S, Detienne M (2015) Summit acid crater lakes and flank instability in composite volcanoes. In: Rouwet D, Christenson B, Tassi F, Vandemeulebrouck J (eds) Volcanic lakes. IAVCEI series advances in volcanology. Springer, Heidelberg, pp 289-306. https://doi. org/10.1007/978-3-642-36833-2_12

Di Piazza A, Rizzo AL, Barberi F, Carapezza ML, De Astis G, Romano C, Sortino F (2015) Geochemistry of the mantle source and magma feeding system beneath Turrialba volcano, Costa Rica. Lithos 232:319-335. https://doi. org/10.1016/j.lithos.2015.07.012

Fernández M, Mora MF, Barquero RP (1998) Los procesos sísmicos en el volcán Irazú. Rev Geol Amér Central 21:47-59 
Gammons CH, Wood SA, Pedrozo F, Varekamp JC, Nelson BJ, Shope CL, Baffico G (2005) Hydrogeochemistry and rare earth element behavior in a volcanically acidified watershed in Patagonia, Argentina. Chem Geol 222:249-267

Giggenbach WF (1988) Geothermal solute equilibria. Derivation of Na-K-MgCa geoindicators. Geochim Cosmochim Acta 52:2149-2765

Goldsmith GR, Munóz-Villers E, Holwerda F, McDonnel JJ, Asbjornsen H, Dawson TE (2011) Stable isotopes reveal linkages among ecohydrological processes in a seasonally dry tropical montane cloud forest. Ecohydrology. https://doi.org/10.1002/eco.268

González G, Mora-Amador R, Ramírez Umaña C, Rouwet D, Alpízar Y, Picado C, Mora R (2015) Actividad histórica y análisis de la amenaza del volcán Turrialba, Costa Rica. Rev Geol Amér Central 52:129-149. https://doi.org/ 10.15517/rgc.v0i52.19033

Heikens A, Sumarti S, van Bergen MJ, Widianarlo B, Fokkert L, Van Leeuwin K, Seinen W (2005) The impact of hyperacid ljen Crater Lake, risks of excess fluoride to human health. Sci Tot Environ 346:56-69

Holwerda F, Bruijnzeel LA, Munóz-Villers LE, Equihua M, Asbjornsen, (2010) Rainfall and cloud water interception in mature and secondary lower montane cloud forests of central Veracruz, Mexico. J Hydrol 384:84-96

Ingebritsen SE, Galloway DL, Collard EM, Sorey ML, Mariner RH (2001) Timevariation of hydrothermal discharge at selected sites in western United States: implications for monitoring. J Volcanol Geotherm Res 111:1-23

Kerle N, van Wijck de Vries B (2001) The 1998 debris avalanche at Casita volcano, Nicaragua-Investigation of structural deformation as the cause of slope instability using remote sensing. J Volcanol Geotherm Res 105:49-63

Kerle N, van Wijck de Vries B, Oppenheimer C (2003) New insights into the factors leading to the 1998 flank collapse and lahar disaster at Casita volcano, Nicaragua. Bull Volcanol 65:331-345

Löhr A, Bogaard TA, Heikens A, Hendriks MR, Sumarti S, van Bergen MJ, Van Gestel CAM, Van Straalen NM, Vroon PZ, Widianarko B (2005) Natural pollution caused by the extremely acidic crater lake Kawah ljen, East Java, Indonesia. Environ Sci Pollut Res 12(2):89-95

López DL, Williams SN (1993) Catastrophic volcanic collapse: relation to hydrothermal processes. Science 260:1794-1796

Manville V (2015) Volcano-hydrologic hazards from volcanic lakes. In: Rouwet D, Christenson B, Tassi F, Vandemeulebrouck J (eds) volcanic lakes. Springer, Heidelberg. https://doi.org/10.1007/978-3-642-36833-2_2

Martini F, Tassi F, Vaselli O, Del Potro R, Martínez M, Van der Laat R, Fernández E (2010) Geophysical, geochemical and geodetical signals of reawakening at Turrialba volcano (Costa Rica) after almost 150 years of quiescence. J Volcanol Geotherm Res 198:416-432

Mick E, Stix J, de Moor JM, Avard G (2021) Hydrothermal alteration and sealing at Turrialba volcano, Costa Rica, as a mechanism for phreatic eruption triggering. J Volcanol Geotherm Res. https://doi.org/10.1016/j.jvolgeores. 2021.107297

Moore JN, Christenson BW, Allis RG, Browne PRL, Lutz SJ (2004) The mineralogical consequences and behavior of descending acid-sulfate waters: An example from the Karaha - Telaga Bodas geothermal system, Indonesia. Can Miner 42:1483-1499

Moore JN, Allis RG, Nemcock M, Powell TS, Bruton CJ, Wanamaker P, Raharjo IB, Norman DI (2008) The evolution of volcano-hosted geothermal systems based on deep wells from Karaha-Telaga Bodas, Indonesia. Am J Sci 308(1):1-48

Mora-Amador RA, Ramírez C, Fernández M (2004) La actividad de los volcanes de la Cordillera Central, Costa Rica, entre 1998-2002. Rev Geol Amér Central 30:189-197

Mora-Amador RA, Rouwet D, Vargas P, Oppenheimer C (2019) The extraordinary sulfur volcanism of Poás from to. In: Tassi F, Vaselli O, Mora-Amador RA (eds) Poás Volcano, active volcanoes of the world. Springer, Heidelberg. https://doi.org/10.1007/978-3-319-02156-0_3

Moussalam Y, Peters N, Ramírez C, Oppenheimer C, Aiuppa A, Giudice G (2014) Characterisation of the magmatic signature in gas emissions from Turrialba Volcano, Costa Rica. Solid Earth 5:1341-1350. https://doi.org/10. 5194/se-5-1341-2014

Muller C, Pacheco J, Angarita M, Alvarado GE, Sánchez B, Avard G (2020) El deslizamiento de las Torres del Irazú del 2020 (Costa Rica): antecedentes, colapso y situación actual. Internal report OVSICORI-UNA, CNE. pp 34 http://www.ovsicori.una.ac.cr/index.php/vulcanologia/deslizamie nto-volcan-irazu
Munóz-Villers LE, Holwerda F, Gomez-Cárdenas Mm Equinhua M, Asbjornsen H, Bruijnzeel LA, Marín-Castro BE, Tobón C (2012) Water balances of old-growth and regenerating montane cloud forests in central Veracruz, Mexico. J Hydrol 462-463:53-66

Murata KJ, Dóndoli C, Sáenz R (1966) The 1963-65 eruption of Irazú Volcano, Costa Rica (the period of March 1963 to October 1964). Bull Volcanol 29:765-796

Palandri JL, Reed M (2001) Reconstruction in situ composition of sedimentary formation waters. Geochim Cosmochim Acta 65:1741-1767

Pang ZH, Reed M (1998) Theoretical chemical thermometry on geothermal waters: problems and methods. Geochim Cosmochim Acta 62(6):1083-1091

Parkhurst DL, Appelo CAJ (1999) User's guide to PHREEQC - a computer program for speciation, batch-reaction, one-dimensional transport, and inverse geochemical calculations. USGS Water Resour Investig Rep 312:99-4259

Parnell RA Jr, Burke KJ (1990) Impacts of acid emissions from Nevado del Ruíz volcano, Colombia, on selected terrestrial and aquatic ecosystems. J Volcanol Geotherm Res 42:69-88

Pavanelli N (2006) La pericolosità del Vulcano Irazú (Costa Rica): dall'attività eruttiva ai movimenti di massa. PhD Thesis, Department of Earth Science, University of Florence, Florence, Italy

Peiffer L, Rouwet D, Taran YA (2015) Fluid geochemistry of El Chichón volcanohydrothermal system. In: Scolamacchia T (ed) Macías JL. Active volcanoes of Chiapas, El Chichón and Tacaná, pp 77-96. https://doi.org/10.1007/ 978-3-642-25890-9_4

Ramírez R, Cordero C, Alvarado GE (2013) Variaciones y características en los cambios de nivel de la Laguna cratérica del volcán Irazú (1965-2012), Costa Rica. Rev Geol Amér Central 48:141-157

Reagan MK, Gill JB (1989) Coexisting calcalkaline and high-niobium basalts from Turrialba Volcano, Costa Rica: implications for residual titanates in arc magma sources. J Geophys Res 94(B4):4619-4633

Reagan M, Duarte E, Soto GJ, Fernández E (2006) The eruptive history of Turrialba volcano, Costa Rica, and potential hazards from future eruptions. In: Rose WI, Bluth GJS, Carr MJ, Ewert J, Patino LC, Vallance J (eds) Volcanic hazards in Central America. Geol Soc Am Special Pap 412:235-257. https://doi.org/10.1130/2006.2412 (13)

Reed M (1982) Calculation of multicomponent chemical equilibria and reaction processes in systems involving minerals, gases, and an aqueous phase. Geochim Cosmochim Acta 46:513-528

Reid ME (2004) Massive collapse of volcanic edifices triggered by hydrothermal pressurization. Geology 32:373-376

Rizzo AL, Di Piazza A, de Moor JM, Alvarado GE, Avard G, Carezza ML, Mora MM (2017) Eruptive activity at Turrialba volcano (Costa Rica): Inferences from ${ }^{3} \mathrm{He} /{ }^{4} \mathrm{He}$ in fumarole gases and chemistry of the products ejected during 2014 and 2015. Geochem Geophys Geosyst 17:4478-4494. https://doi. org/10.1002/2016GC006525

Romano P, Liotta M (2018) Using and abusing Giggenbach ternary Na-K-Mg diagram. Chem Geol 541:119577. https://doi.org/10.1016/j.chemgeo. 2020.119577

Rouwet D (2011) A photographic method for detailing the morphology of the floor of a dynamic crater lake: the El Chichón case (Chiapas, Mexico). Limnology 12:225-233. https://doi.org/10.1007/s10201-011-0343-7

Rouwet D (2021) Volcanic lake dynamics and related hazards. In: Papale P (ed) Forecasting and planning for volcanic hazards, risks and disasters. Elsevier, Amsterdam. https://doi.org/10.1016/B978-0-12-818082-2.00011-1

Rouwet D, Inguaggiato S, Taran Y, Varley N, Santiago Santiago JA (2009) Chemical and isotopic compositions of thermal springs, fumaroles and bubbling gases at Tacaná Volcano (Mexico-Guatemala): implication for volcanic surveillance. Bull Volcanol 71:319-335. https://doi.org/10.1007/ s00445-008-0226-x

Rouwet D, Tassi F, Mora-Amador R, Sandri L, Chiarini V (2014a) Past, present and future of volcanic lake monitoring. J Volcanol Geotherm Res 272:78-97. https://doi.org/10.1016/j.jvolgeores.2013.12.009

Rouwet D, Sandri L, Marzocchi W, Gottsmann J, Selva J, Tonini R, Papale P (2014b) Recognizing and tracking volcanic hazards related to nonmagmatic unrest: a review. J Appl Volcanol 3:17. https://doi.org/10.1186/ s13617-014-0017-3 
Rouwet D, Mora-Amador R, Ramírez-Umaña C, González G, Lucchi F, Forni F, Sulpizio R, Baldoni E, Alpízar-Segura Y, Tranne CA (2015) First documentation of the ongoing phreatic-strombolian eruptions of Turrialba volcano (Costa Rica). Abstract 26th IUGG General Assembly, 3746

Rouwet D, Mora-Amador R, Ramírez-Umaña CJ, González G, Inguaggiato S (2017) Dynamic fluid recycling at Laguna Caliente (Poás, Costa Rica) before and during the 2006-ongoing phreatic eruption cycle (2005-10). In: Ohba T, Capaccioni B, Caudron C (Eds), Geochemistry and geophysics of active crater lakes. Geol Soc London Special Publication pp 437. https://doi.org/10.1144/SP437.11

Rowe GL Jr, Brantley SL, Fernández M, Fernández JF, Borgia A, Barquero J (1992) Fluid-volcano interaction in an active stratovolcano: the crater lake system of Poás volcano, Costa Rica. J Volcanol Geotherm Res 49:23-51

Rowe GL Jr, Brantley SL, Fernández JF, Borgia A (1995) The chemical and hydrologic structure of Poás volcano, Costa Rica. J Volcanol Geotherm Res 64:233-267

Sanford WE, Konikow LF, Rowe GL Jr, Brantley SL (1995) Groundwater transport of crater-lake brine at Poás Volcano, Costa Rica. J Volcanol Geotherm Res 64:269-293

Stix J, de Moor JM (2018) Understanding and forecasting phreatic eruptions driven by magmatic degassing. Earth Planets Space 70:83. https://doi. org/10.1186/s40623-018-0855-z

Taran Y, Kalacheva E (2020) Acid sulfate-chloride volcanic waters: Formation and potential for monitoring of volcanic activity. J Volcanol Geotherm Res 405:107036. https://doi.org/10.1016/j.jvolgeores.2020.107036

Taran YA, Peiffer L (2009) Hydrology, hydrochemistry and geothermal potential of El Chichón volcano-hydrothermal system, Mexico. Geothermics 38:370-378

Taran YA, Pokrovsky BG, Rubik YM (1989) Isotopic composition and origin of water from andesitic magma. Doll Ac Sci USSR 304:440-443

Taran YA, Rouwet D, Inguaggiato S, Aiuppa A (2008) Major and trace element geochemistry of neutral and acidic thermal springs at El Chichón volcano, Mexico. Implications for monitoring of the volcanic activity. J Volcanol Geotherm Res 178:224-236

Ulloa A, Campos-Fernández CS, Rojas L (2013) Cueva los minerales, Volcán Irazú, Costa Rica: descripción, mineralogía y origen. Rev Geol Amér Centr 48:169-187 van Hinsberg V, Berlo K, Sumarti S, van Bergen MJ, Williams-Jones A (2010) Extreme alteration by hyperacidic brines at Kawah ljen volcanic, East Java, Indonesia: II Metasomatic imprint and element fluxes. J Volcanol Geotherm Res 196:169-184

van Rotterdam-Los AMD, Vriend SP, van Bergen MJ, Van Gaans PFM (2008) The effect of naturally acidified irrigation water on agricultural volcanic soils. The case of Asembagus, Java, Indonesia. J Geochem Explor 96:53-68

van Wijck de Vries B, Kerle N, Petley DN (2000) Sector collapse forming at Casita volcano, Nicaragua. Geology 28:167-170

Varekamp JC (2008) The volcanic acidification of glacial Lake Caviahue, Province of Neuquen, Argentina. J Volcanol Geotherm Res 178:184-196

Varekamp JC (2015) The chemical composition and evolution of volcanic lakes. In: Rouwet D, Christenson B, Tassi F, Vandemeulebrouck J (eds) Volcanic Lakes, IAVCEI Series Advances in Volcanology. Springer, Heidelberg, pp 93-123. https://doi.org/10.1007/978-3-642-36833-2_4

Varekamp JC, Kreulen R (2000) The stable isotope geochemistry of volcanic lakes, with examples from Indonesia. J Volcanol Geothermal Res 97:309-327

Varekamp JC, Ouimette AP, Herman SW, Delpino D, Bermúdez A (2001) The 1990-2000 eruptions of Copahue, Argentine: a "bee-hive volcano" in turmoil. Geology 29:1059-1062

Varekamp JC, Ouimette AP, Herman SW, Flynn KS, Bermúdez A, Delfino D (2009) Naturally acid waters from Copahue volcano, Argentina. Appl Geochem 24:208-220

Vaselli O, Tassi F, Duarte E, Fernández E, Poreda RJ, Delgado Huertas A (2009) Evolution of fluid geochemistry at the Turrialba volcano (Costa Rica) from 1998 to 2008. Bull Volcanol. https://doi.org/10.1007/s00445-009-0332-4

Voight B, Ellsworth D (1997) Failure of volcano slopes. Geotechnique 47:1-31

Voight B, Janda RJ, Glicken H, Douglas PM (1983) Nature and mechanics of the Mount St. Helens rockslide-avalanche of 18 May 1980. Geotechnique 33:243-273

\section{Publisher's Note}

Springer Nature remains neutral with regard to jurisdictional claims in published maps and institutional affiliations.

\section{Submit your manuscript to a SpringerOpen ${ }^{\odot}$ journal and benefit from:}

- Convenient online submission

- Rigorous peer review

- Open access: articles freely available online

- High visibility within the field

- Retaining the copyright to your article

Submit your next manuscript at $\boldsymbol{\Delta}$ springeropen.com 